\title{
Is There a Pattern for Occurrence of Macrophytes in Polish Ponds?
}

\author{
Dariusz Świerk *(1) and Michał Krzyżaniak (D) \\ Department of Landscape Architecture, Poznan University of Life Sciences, 60-637 Poznań, Poland \\ * Correspondence: dariusz.swierk@up.poznan.pl; Tel.: +48-61-848-79-92
}

Received: 8 July 2019; Accepted: 18 August 2019; Published: 21 August 2019

\begin{abstract}
Although ponds are common elements in the environment, dependences occurring in these ecosystems have not been fully investigated. Our study focuses on the correlation between environmental factors and changes occurring in ponds-mostly the distribution of macrophytes in space and time. The aim of our analyses was to indicate which physicochemical variables were characteristic of ponds in specific habitats (forest, agriculture field, and village) and whether they could associate the distribution of vegetation in these ponds. Thirteen ponds differing in morphometric parameters and location in landscape (ponds located in agriculture fields, forests, and villages) were analyzed. Our research was based on data covering a period of 10 years (2008-2018). The following parameters were analyzed: the water content of $\mathrm{NH}_{4}{ }^{+}, \mathrm{NO}_{3}{ }^{-}, \mathrm{NO}_{2}{ }^{-}, \mathrm{TP}, \mathrm{PO}_{4}{ }^{3-}, \mathrm{Na}, \mathrm{K}, \mathrm{Mg}, \mathrm{Ca}$, and $\mathrm{Fe}, \mathrm{pH}$, temperature and morphometric parameters. Macrophytes were observed during the growing season in July 2008, 2010, 2012, 2014, 2016 and 2018. Three homogeneous species groups were distinguished in statistical analyses and the dominance of selective environmental factors was assigned to them. The first group consisted of indicator species for forest ponds. Their waters were characterized by a low content of $\mathrm{Ca}, \mathrm{Mg}$, and $\mathrm{Na}$ as well as an increased content of $\mathrm{NH}_{4}{ }^{+}$and Fe. The second group was composed of indicator species for field ponds, where the highest $\mathrm{NO}_{3}{ }^{-}$ concentrations were found. The third group was formed by indicator species for village ponds. Water of these ponds was characterized by higher concentration levels of $\mathrm{K}, \mathrm{Na}$, and total $\mathrm{P}$.
\end{abstract}

Keywords: macrophytes; environmental factors; agricultural areas

\section{Introduction}

Ponds (standing waterbodies from $25 \mathrm{~m}^{2}$ to 2 ha in size [1]) in agricultural landscapes are very common and they cover more than $3 \%$ of the Earth's terrestrial surface area [2,3]. Ponds are the most numerous representatives of inland standing waters [4]. They host unique flora and contribute to regional biodiversity [5-7]. The information about the value of ponds is insufficient [8]. Little is known about their environmental sensitivity, structure, functioning, relations with the surrounding landscapes, and how they are affected by human activity [9]. Currently, there is a growing interest in pond ecology $[4,6]$, mostly due to the recent revelation and acknowledgement of their general ecological importance [2]. Small farmland ponds are especially vulnerable to climate change and habitat degradation (including pollution) due to their limited volume [2,7,10-12]. The estimated loss of ponds in the 20th century exceeded 50\% in many European countries [13], and was up to $90 \%$ in some regions due to agricultural land drainage and urbanisation $[7,14]$. Recognising the loss of ponds, restoration and reconstruction projects were recently implemented in several regions worldwide [4]. Ponds may act as important surrogate habitats for species whose natural habitats have been lost [15]. Ponds may increase the biodiversity of macrophytes and positively affect the occurrence of larger amounts of rare and endemic plant species more so than other freshwater habitats [1,2]. However, we generally lack information as to how freshwater habitats, including ponds, support biodiversity [4]. Most farmland 
ponds have small catchment areas and specific physicochemical properties [16]. All these variables cause considerable differences in habitat conditions between big and small ponds [17-19]. In view of their potentially high ecological value, information about their biological quality is essential for long-term conservation and management of biodiversity [20].

Macrophytes create an environment that is fundamentally different from that of the open water and that potentially may have great impact on the interactions between the different trophic levels [21]. The diversity of macrophytes may increase with the abundance and proximity of other wetland habitats in the landscape [22], but this is not necessarily always the case [23], and the positive effect of connectivity may even be reversed by the presence of strong ecological interactions in connected waterbodies [24]. The regional effects associated with intensive land use (farmlands or urban areas) are very typical for decreasing macrophyte diversity [25]. A high degree of variability also exists in the relationships between the local environment and the diversity of pond-dwelling macrophytes, but surface area, water chemistry and the hydrological regime are usually ranked among the most influential local factors [26]. Macrophytes from different groups are likely to respond to the variability of the pond environment in different ways, resulting in different diversity patterns $[25,27]$. Freshwater macrophyte diversity is highly variable because it may involve interactions of several environmental factors [26]. Aquatic plants may also reduce the content of nutrients and water turbidity [28,29]. This group can be used as bioindicators because it reacts to changes in the environment and helps to predict changes in ecosystems [30,31]. Rooted submerged macrophytes play an important role in nutrient cycling in ponds by mediating fluxes of nutrients from sediments into the water [29]. Macrophytes mobilize nutrients either directly (from sediments through root uptake and senescence) or indirectly (from sediments by causing marked fluctuations in $\mathrm{pH}$ and oxygen, which enhance the rate of $\mathrm{P}$ release from sediments) [32]. In particular, high $\mathrm{pH}$ values (about 9-10) associated with macrophyte photosynthesis can result in ligand exchange with $\mathrm{P}$ adsorbed to iron oxide-hydroxides on sediment particles, thus enhancing the rate of $P$ release from sediments [32].

The hypotheses of our research were: (1) the morphometric variables and physio-chemical properties of water are correlated with the distribution of rooted and floating macrophytes in ponds; (2) there are macrophyte species characteristic of a specific location. The overall aim of the study was to test if there is a correlation between macrophytes' (rooted and floating) temporal changes and the influence of environmental factors on the ecosystems of ponds in the reference period (2008-2018). The second aim was to assess whether the pond ecosystems (similar in terms of land use) can be characterized by a similar composition of macrophytes.

\section{Materials and Methods}

The research was conducted on 13 ponds located in the General Dezydery Chłapowski Scenic Park in Greater Poland Voivodeship, Poland. No specific permissions were required for the locations. It is clearly stated in the XLIV/858/14 Bill of Wielkopolska Voivodeship Parliament (28 April 2014) regarding establishment of the General Dezydery Chłapowski Scenic Park. Our field studies did not involve any endangered or protected species. The ponds differed in their location in the landscape, surface area, shape, and aquatic vegetation. The geographical coordinates and changes in the morphometric parameters of the ponds under analysis are presented in Table 1. Some ponds were typical field hollows, others were in built-up areas, and two were in a forest complex (Figure 1). 
Table 1. The morphometric parameters of ponds.

\begin{tabular}{|c|c|c|c|c|c|c|c|c|c|c|c|c|c|}
\hline \multirow{3}{*}{ Location } & \multicolumn{2}{|c|}{ Forest } & \multicolumn{6}{|c|}{ Agriculture Field } & \multicolumn{5}{|c|}{ Village } \\
\hline & 1 & 2 & 3 & 5 & 9 & 10 & 11 & 12 & 4 & 6 & 7 & 8 & 13 \\
\hline & $\begin{array}{l}52^{\circ} 03^{\prime} 19.4^{\prime \prime} \mathrm{N} \\
16^{\circ} 55^{\prime} 44.9^{\prime \prime} \mathrm{E}\end{array}$ & $\begin{array}{l}52^{\circ} 03^{\prime} 45.1^{\prime \prime} \mathrm{N} \\
16^{\circ} 54^{\prime} 27.7^{\prime \prime} \mathrm{E}\end{array}$ & $\begin{array}{l}52^{\circ} 05^{\prime} 38.3^{\prime \prime} \mathrm{N} \\
16^{\circ} 47^{\prime} 16.4^{\prime \prime} \mathrm{E}\end{array}$ & $\begin{array}{l}52^{\circ} 03^{\prime} 39.4^{\prime \prime} \mathrm{N} \\
16^{\circ} 52^{\prime} 13.2^{\prime \prime} \mathrm{E}\end{array}$ & $\begin{array}{l}52^{\circ} 02^{\prime} 31.1^{\prime \prime} \mathrm{N} \\
16^{\circ} 49^{\prime} 31.0^{\prime \prime} \mathrm{E}\end{array}$ & $\begin{array}{l}52^{\circ} 02^{\prime} 31.0^{\prime \prime} \mathrm{N} \\
16^{4} 49^{\prime} 18.2^{\prime \prime} \mathrm{E}\end{array}$ & $\begin{array}{l}52^{\circ} 03^{\prime} 27.7^{\prime \prime} \mathrm{N} \\
16^{\circ} 50^{\prime} 12.5^{\prime \prime} \mathrm{E}\end{array}$ & $\begin{array}{l}52^{\circ} 01^{\prime} 08.5^{\prime \prime} \mathrm{N} \\
16^{\circ} 46^{\prime} 29.9^{\prime \prime} \mathrm{E}\end{array}$ & $\begin{array}{l}52^{\circ} 03^{\prime} 41.7^{\prime \prime} \mathrm{N} \\
16^{4} 48^{\prime} 55.7^{\prime \prime} \mathrm{E}\end{array}$ & $\begin{array}{l}52^{\circ} 02^{\prime} 32.3^{\prime \prime} \mathrm{N} \\
16^{\circ} 52^{\prime} 09.8^{\prime \prime} \mathrm{E}\end{array}$ & $\begin{array}{l}52^{\circ} 01^{\prime} 20.2^{\prime \prime} \mathrm{N} \\
16^{\circ} 51^{\prime} 33.4^{\prime \prime} \mathrm{E}\end{array}$ & $\begin{array}{l}52^{\circ} 01^{\prime} 16.5^{\prime \prime} \mathrm{N} \\
16^{\circ} 51^{\prime} 25.8^{\prime \prime} \mathrm{E}\end{array}$ & $\begin{array}{l}52^{\circ} 02^{\prime} 58.7^{\prime \prime} \mathrm{N} \\
16^{\circ} 47^{\prime} 12.7^{\prime \prime} \mathrm{E}\end{array}$ \\
\hline Years & & & & & & & Area $\left(\mathrm{m}^{2}\right)$ & & & & & & \\
\hline 2008 & 92 & 885 & 2538 & 1668 & 1929 & 919 & 3026 & 4756 & 1344 & 1992 & 358 & 432 & 1173 \\
\hline 2010 & 113 & 887 & 2589 & 1685 & 1929 & 1012 & 2937 & 5062 & 1452 & 2033 & 389 & 445 & 1214 \\
\hline 2012 & 119 & 907 & 2411 & 1610 & 1913 & 924 & 2837 & 3212 & 1432 & 1981 & 372 & 425 & 1113 \\
\hline 2014 & 108 & 917 & 2407 & 1412 & 1862 & 874 & 2731 & 893 & 1307 & 1877 & 350 & 413 & 1097 \\
\hline 2016 & 72 & 905 & 2387 & 1587 & 1907 & 1001 & 2841 & 3257 & 1497 & 2075 & 387 & 427 & 1212 \\
\hline 2018 & 55 & 909 & 2613 & 1452 & 1702 & 921 & 2717 & 3357 & 1472 & 1916 & 312 & 397 & 1187 \\
\hline mean & 93 & 902 & 2491 & 1569 & 1873 & 942 & 2848 & 3423 & 1417 & 1979 & 361 & 423 & 1166 \\
\hline$\Delta \%$ & -41.0 & 0.8 & 4.9 & -7.5 & -9.2 & -2.2 & -4.6 & -1.9 & 3.9 & -3.2 & -13.7 & -6.2 & 1.8 \\
\hline SD & 25.2 & 12.8 & 101.0 & 112.9 & 87.6 & 53.5 & 118.8 & 1479.2 & 75.2 & 73.0 & 28.7 & 16.5 & 49.9 \\
\hline Years & & & & & & & Depth (m) & & & & & & \\
\hline 2008 & 0.30 & 0.43 & 0.70 & 0.37 & 0.52 & 0.67 & 1.52 & 0.41 & 0.92 & 0.58 & 0.42 & 0.38 & 0.87 \\
\hline 2010 & 0.32 & 0.44 & 0.81 & 0.41 & 0.62 & 0.69 & 1.47 & 0.42 & 0.94 & 0.67 & 0.42 & 0.37 & 0.91 \\
\hline 2012 & 0.30 & 0.51 & 0.71 & 0.38 & 0.60 & 0.61 & 1.44 & 0.21 & 0.91 & 0.62 & 0.41 & 0.36 & 0.88 \\
\hline 2014 & 0.28 & 0.52 & 0.69 & 0.12 & 0.49 & 0.51 & 1.41 & 0.15 & 0.82 & 0.59 & 0.37 & 0.35 & 0.70 \\
\hline 2016 & 0.19 & 0.50 & 0.66 & 0.39 & 0.57 & 0.66 & 1.47 & 0.20 & 0.90 & 0.69 & 0.40 & 0.36 & 0.90 \\
\hline 2018 & 0.15 & 0.52 & 1.40 & 0.15 & 0.43 & 0.52 & 1.40 & 0.22 & 0.91 & 0.66 & 0.27 & 0.30 & 0.88 \\
\hline mean & 0.26 & 0.49 & 0.83 & 0.30 & 0.54 & 0.61 & 1.45 & 0.27 & 0.90 & 0.64 & 0.38 & 0.35 & 0.86 \\
\hline$\Delta \%$ & -41.56 & 6.85 & 69.01 & -50.55 & -20.12 & -14.75 & -3.56 & -18.01 & 1.11 & 3.94 & -29.26 & -15.09 & 2.72 \\
\hline SD & 0.07 & 0.04 & 0.28 & 0.13 & 0.07 & 0.08 & 0.04 & 0.12 & 0.04 & 0.05 & 0.06 & 0.03 & 0.08 \\
\hline
\end{tabular}



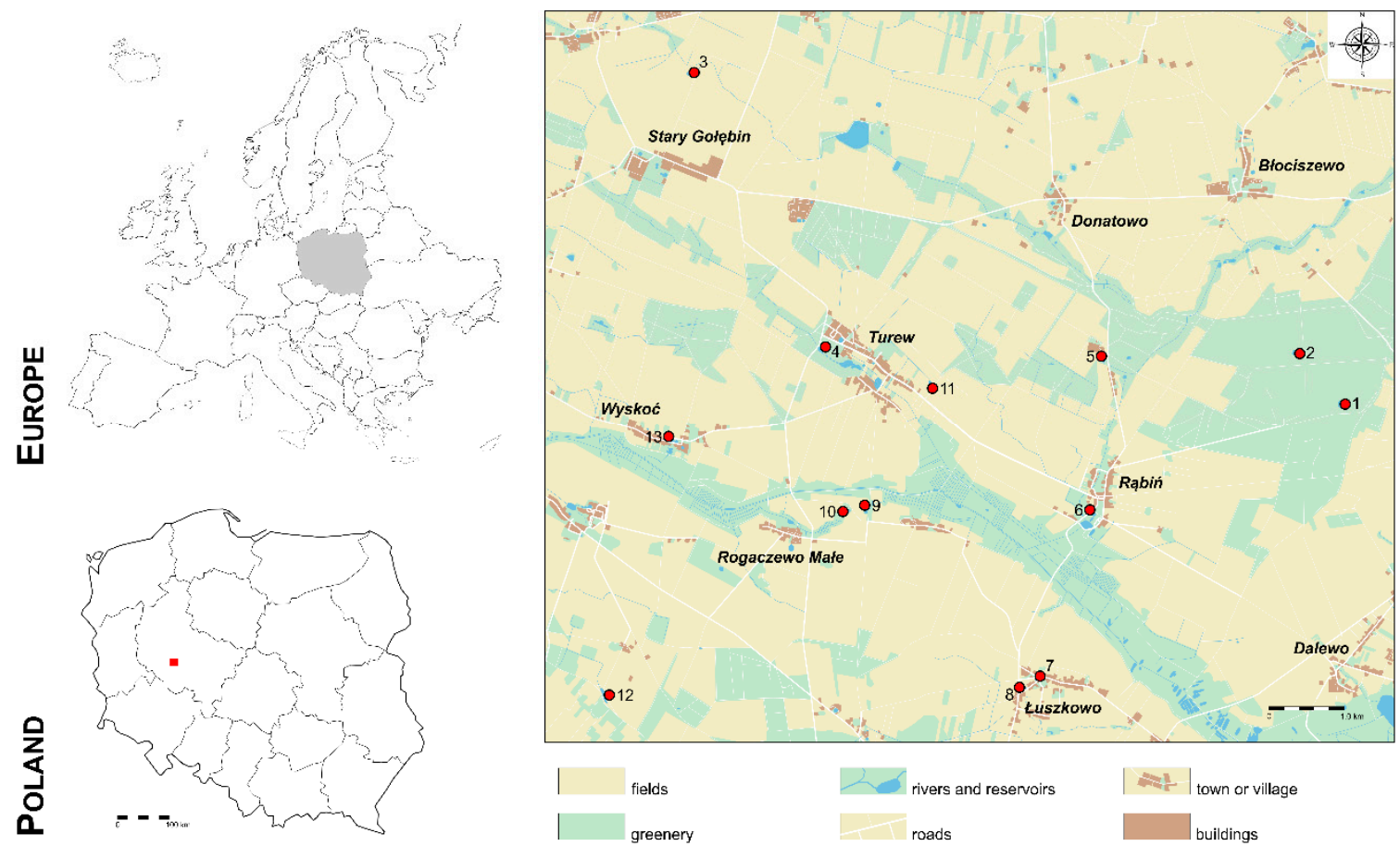

Figure 1. The location of the research objects.

Forest ponds (Nos. 1 and 2) were in the planted forests: Pond No. 1-deciduous forest, and Pond No. 2-coniferous forest. Pond No. 1 was a natural reservoir, while Pond No. 2 was created in the 1990s. Field ponds (Nos. 3, 5, 9, 10,11,12) were all natural reservoirs with the exception of No. 9, which was created by the Polish Academy of Sciences for scientific purposes in 1995. Pond No. 3-surrounded by fields, cultivation of maize, fertilized organically and by minerals. Pond No. 5-surrounded by fields, rye, and wheat cultivation, fertilized organically and by minerals. Pond No. 9-surrounded by meadow, field, and a paved road; rye, wheat, and rape cultivation; fertilized organically and by minerals. Pond No. 10—surrounded by fields; rye cultivation; fertilized organically and by minerals. Pond No. 11-surrounded by fields and a meadow; cultivation of wheat and rape; fertilized organically and by minerals. Pond No. 12-surrounded by fields; cultivation of wheat and rape; fertilized organically and by minerals. Village ponds (Nos. 4, 6, 7, 8, and 13) were ponds created in the villages, without drainage, with the exception of No. 4, which was a natural pond. No wastewater was supplied to any pond and no wastewater was collected. Humans affected none of the ponds directly (e.g., fishing). Pond No. 4-surrounded by an old park where deciduous trees grow. Pond No. 6-surrounded by roads and meadows. Ponds Nos. 7, 8 and 13-located in the center of the village, surrounded by buildings and roads.

$\Delta$ (the delta symbol) means the increase or decrease in area and depth in 2018 in relation to the mean area and depth calculated from the ten-year period and is expressed as a percentage:

$$
\Delta=\left(\mathrm{A}_{2018} / \mathrm{A}_{\text {mean }} \times 100-100\right)[\%] \text {, }
$$

$\mathrm{A}_{2018}$-area and depth in 2018.

$\mathrm{A}_{\text {mean }}$-mean area and depth.

The research spanned a period of ten years (2008-2018), with measurements made every second year. The surface of the studied ponds was measured by a qualified surveyor using the Pentax R-1500N (TI Asahi Co., Ltd., Saitama, Japan) total station theodolite with TopoLite software (TI Asahi Co., Ltd., Saitama, Japan), and mean depth was measured by a depth pole (Figure 2). 


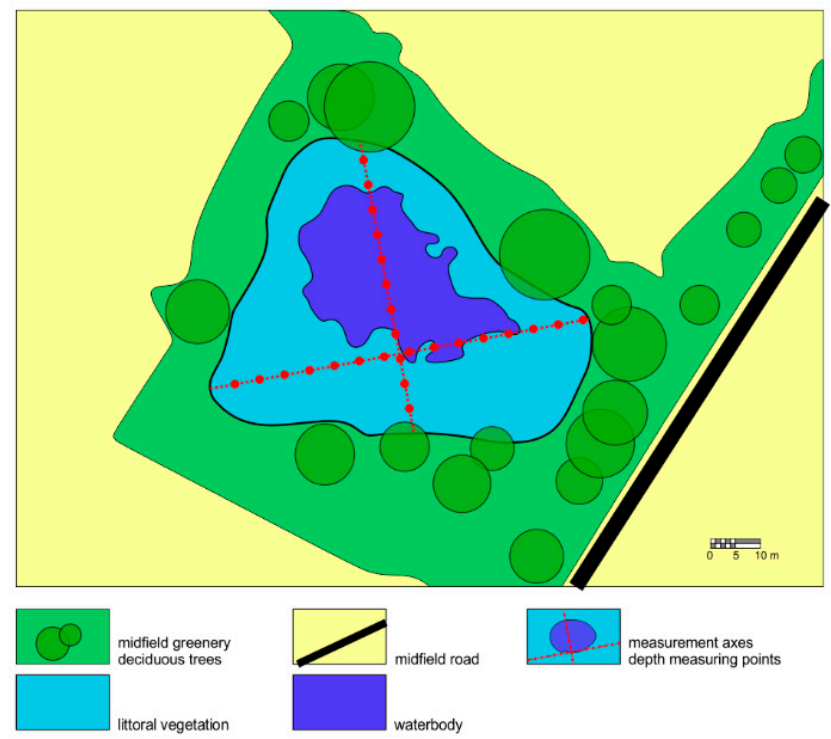

Figure 2. Waterbody depth and temperature measurement scheme (the example given is of pond No. 11).

The morphometric parameters, such as the depth and area of ponds, were measured at the beginning of July in 2008, 2010, 2012, 2014, 2016, and 2018-six times in total during the research period. Macrophytes were identified at the beginning of July and then verified twice (on 15 July and 31 July in terms of area they occupied) in the research year, which gives three observations per year. This was the optimal period for the identification of macrophytes during the growing season. Similarly, physicochemical parameters of water in ponds were collected and tested (three observations per year).

Samples of water were analyzed for the content of $\mathrm{NH}_{4}{ }^{+}, \mathrm{NO}_{3}{ }^{-}, \mathrm{NO}_{2}{ }^{-}, \mathrm{TP}, \mathrm{PO}_{4}{ }^{3-}, \mathrm{Na}, \mathrm{K}, \mathrm{Mg}$, $\mathrm{Ca}$, and $\mathrm{Fe}-$ according to standard methods [33]. The $\mathrm{pH}$ value and temperature were also measured using a waterproof CP-411 device with a glass electrode EPS- 1 type. We collected water samples at depths of 20-50 cm, about $1 \mathrm{~m}$ away from the shore of ponds.

The following methods were used to analyze the content of elements in AAS AAnalyst 200 spectrometer with specific optimisation parameters (Table A1):

- Flame Atomic Absorption Spectrometry (F-AAS)—Ca, Mg, and Fe;

- Atomic Emission Spectrometry (AES)-Na, K.

In order to determine the differences between ponds in terms of anthropogenic pressure, the ECELS methodology proposed by Sala et al. [34] was used. The index is composed of five components (morphology, human activity, water aspects, emergent vegetation, hydrophytic vegetation), each assessing an independent aspect of the conservation status of a wetland. Each component has a modifying section that assesses additional particularities of the component where one or several options can be chosen resulting in addition or subtraction of points. The score obtained for each component cannot exceed a maximum value nor have negatives values. The maximum values of the five components are 20,20,10,30 and 20, respectively. The sum of all the values obtained for each component gives the ECELS index final score, which can range between 0 and 100. A categorization of the values is proposed following the guidelines of the Water Framework Directive (2000/60/EC).

The species composition of macrophytes in the 13 ponds was investigated every second year during the ten-year research period (2008-2018). The species of macrophytes in ponds were listed and the percentage of the area occupied by dominant species (a share of over $1 \%$ in pond) was determined [35].

In order to determine the indicator species for ponds in different land use types, the IndVal method described by Dufrêne and Legendre [36] was used. For each species $i$ in each site group $j$, we 
computed the product of $A_{i j}$ (which is the mean abundance of species $i$ in the sites of group $j$ compared to all groups in the study) by $B_{i j}$, which is the relative frequency of occurrence of species $i$ in the sites of group j, as follows:

$$
\begin{gathered}
A_{i j}=\text { Nindividuals }_{i j} / \text { Nindividuals }_{i}, \\
B_{i j}=\text { Nsites }_{i j} / \text { Nsites }_{j}, \\
\text { IndVal }_{i j}=A_{i j} \times \mathrm{B}_{i j} \times 100 .
\end{gathered}
$$

Nindividuals $i j$ - the mean number of individuals of species $i$ across sites of group $j$.

Nindividuals $s_{i}$ - the sum of the mean numbers of individuals of species $i$ over all groups.

Nsites $_{i j}$ - the number of sites in cluster $j$ where species $i$ is present.

Nsites $_{j}$ - the total number of sites in that cluster. $B_{i j}$ reaches a maximum when species $i$ is present in all objects of cluster $j$.

Latin names of the macrophytes were used according to the Plant List [37].

Statistical analyses and models were based on discriminant analysis. Canonical variate analysis (CVA), which is the canonical variant of Fisher's linear discriminant analysis (LDA), was used to construct a CCA analysis [38]. Progressive stepwise analysis was applied to find which variables determined the distribution of macrophytes in ponds to the greatest extent. CCA analysis was preceded by stepwise regression analysis, which eliminated statistically insignificant variables $(p>0.05$ and $\mathrm{F}<2$ ). A Monte Carlo permutation test was applied to determine the significance limit (the number of permutations: 9999). We have also applied linear regression, multiple regression and correlations in presented paper. All multiple regression and ANOVA analyses were performed with the PQstat software.

\section{Results}

Figure 3 presents the ranges of ECELS values for ponds located in areas near forests, fields and villages. According to the analysis, the highest values (good and moderate) were characteristic of ponds located in the forest. Village ponds, on the other hand, corresponded to poor and bad levels of the ECELS indicator. The low scores were associated with components related to human activity around the ponds and the lack of submerged and floating macrophytes (Table 2).

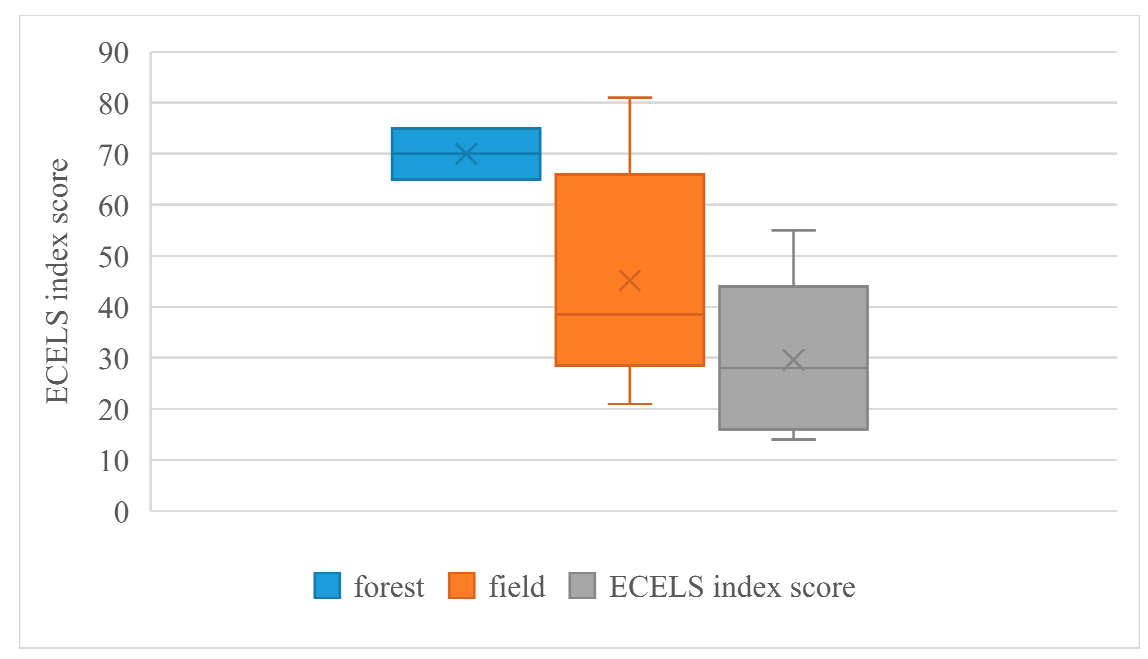

Figure 3. ECELS index score for ponds according to land use. 
Table 2. The value of ECELS components for ponds according to land use.

\begin{tabular}{cccc}
\hline Ponds Location & & Mean & SD \\
\hline \multirow{3}{*}{ basin littoral morphology } & forest & 15.0 & 7.1 \\
& field & 7.5 & 8.2 \\
& village & 12.0 & 7.6 \\
\hline \multirow{3}{*}{ human activity } & forest & 20.0 & 0.0 \\
& field & 12.8 & 5.9 \\
& village & 0.2 & 5.4 \\
\hline \multirow{3}{*}{ water characteristics } & forest & 7.5 & 3.5 \\
& field & 6.8 & 1.8 \\
& village & 5.2 & 2.0 \\
\hline \multirow{3}{*}{ emergent vegetation } & forest & 25.0 & 7.1 \\
& field & 11.7 & 9.8 \\
& village & 13.0 & 7.6 \\
\hline \multirow{2}{*}{ hydrophytic vegetation } & forest & 2.5 & 3.5 \\
& field & 6.3 & 5.9 \\
& village & 0.6 & 3.8 \\
\hline
\end{tabular}

The ponds analyzed in the study were found in land transformed by agriculture. They were in forests, fields, and in villages. These ponds were small elements of the environment. By analyzing using repeated measures ANOVA, we can conclude that most ponds differed in terms of change of their area over time. This may indicate that pond area was not influenced by one factor only, but by a group of environmental variables (Table 3).

Table 3. ANOVA analysis: $\mathrm{F}=36.906, p<0.0001$ ( $p$-values determined for area of ponds).

\begin{tabular}{|c|c|c|c|c|c|c|c|c|c|c|c|c|}
\hline & \multicolumn{12}{|c|}{ Pond Number } \\
\hline & 1 & 2 & 3 & 4 & 5 & 6 & 7 & 8 & 9 & 10 & 11 & 12 \\
\hline 2 & 0.0487 & & & & & & & & & & & \\
\hline 3 & 0.0001 & 0.0001 & & & & & & & & & & \\
\hline 4 & 0.0001 & 0.5907 & 0.0016 & & & & & & & & & \\
\hline 5 & 0.0001 & 0.2051 & 0.0122 & 1.0000 & & & & & & & & \\
\hline 6 & 0.0001 & 0.0015 & 0.6017 & 0.4559 & 0.8637 & & & & & & & \\
\hline 7 & 0.9943 & 0.5178 & 0.0001 & 0.0020 & 0.0003 & 0.0001 & & & & & & \\
\hline 8 & 0.9683 & 0.6981 & 0.0001 & 0.0046 & 0.0006 & 0.0001 & 1.0000 & & & & & \\
\hline 9 & 0.0001 & 0.0063 & 0.3100 & 0.7577 & 0.9831 & 1.0000 & 0.0001 & 0.0001 & & & & \\
\hline 10 & 0.0304 & 1.0000 & 0.0001 & 0.7067 & 0.2867 & 0.0026 & 0.4036 & 0.5817 & 0.0107 & & & \\
\hline 11 & 0.0001 & 0.0001 & 0.9434 & 0.0001 & 0.0001 & 0.0237 & 0.0001 & 0.0001 & 0.0060 & 0.0001 & & \\
\hline 12 & 0.0001 & 0.0001 & 0.0107 & 0.0001 & 0.0001 & 0.0001 & 0.0001 & 0.0001 & 0.0001 & 0.0001 & 0.4194 & \\
\hline 13 & 0.0016 & 0.9950 & 0.0001 & 0.9968 & 0.8765 & 0.0462 & 0.0509 & 0.0996 & 0.1414 & 0.9989 & 0.0001 & 0.0001 \\
\hline
\end{tabular}

All ponds were very shallow-their average depth ranged from $15 \mathrm{~cm}$ to $1.5 \mathrm{~m}$. A similar relationship was observed in changes of depth over time in the analyzed ponds. The analysis showed that the changes in depth of tested ponds over time differed significantly in most ponds. Therefore, we cannot say that one factor could have a clear influence on changes of this parameter over time (Table 4). 
Table 4. ANOVA analysis: $\mathrm{F}=64.938, p<0.0001$ ( $p$-values determined for depth of ponds).

\begin{tabular}{|c|c|c|c|c|c|c|c|c|c|c|c|c|}
\hline & \multicolumn{12}{|c|}{ Pond Number } \\
\hline & 1 & 2 & 3 & 4 & 5 & 6 & 7 & 8 & 9 & 10 & 11 & 12 \\
\hline 2 & 0.0152 & & & & & & & & & & & \\
\hline 3 & 0.0001 & 0.0001 & & & & & & & & & & \\
\hline 4 & 0.0001 & 0.0001 & 0.9911 & & & & & & & & & \\
\hline 5 & 0.9999 & 0.1240 & 0.0001 & 0.0001 & & & & & & & & \\
\hline 6 & 0.0001 & 0.3955 & 0.0828 & 0.0024 & 0.0001 & & & & & & & \\
\hline 7 & 0.6608 & 0.8576 & 0.0001 & 0.0001 & 0.9814 & 0.0045 & & & & & & \\
\hline 8 & 0.9142 & 0.5646 & 0.0001 & 0.0001 & 0.9997 & 0.0010 & 1.0000 & & & & & \\
\hline 9 & 0.0010 & 0.9996 & 0.0006 & 0.0001 & 0.0118 & 0.9142 & 0.3123 & 0.1162 & & & & \\
\hline 10 & 0.0001 & 0.6796 & 0.0269 & 0.0006 & 0.0003 & 1.0000 & 0.0165 & 0.0038 & 0.9911 & & & \\
\hline 11 & 0.0001 & 0.0001 & 0.0001 & 0.0001 & 0.0001 & 0.0001 & 0.0001 & 0.0001 & 0.0001 & 0.0001 & & \\
\hline 12 & 1.0000 & 0.0269 & 0.0001 & 0.0001 & 1.0000 & 0.0001 & 0.7845 & 0.9650 & 0.0018 & 0.0001 & 0.0001 & \\
\hline 13 & 0.0001 & 0.0001 & 1.0000 & 0.9999 & 0.0001 & 0.0229 & 0.0001 & 0.0001 & 0.0002 & 0.0064 & 0.0001 & 0.0001 \\
\hline
\end{tabular}

Statistical significance $(p$-value $<0.05)$ in bold.

Macrophytes occupied various surface areas in the researched ponds (Figure 4). Forest ponds were occupied by macrophytes to the smallest extent and had the smallest share of flora species associated with the aquatic environment. Lemna minor L. was a dominating species at the beginning of the research period. However, in the last two years of the study, the largest increase of surface area was found for Juncus effusus L. and Polygonum hydropiper L. A significantly higher percentage of macrophytes' surface area coverage was found in the case of agriculture ponds, where Phragmites australis (Cav.) Trin. ex Steud predominated. Village ponds were characterized by a decrease of Lemna minor L. surface area coverage and an increase in the area occupied mainly by two species: Phragmites australis (Cav.) Trin. ex Steud and Ceratophyllum submersum L.

In order to point out indicator species for different land use areas (forests, fields, villages), the IndVal method was applied [36]. Then, a Monte Carlo test was carried out to determine the probability of a given IndVal value. Table 5 includes those species for which $p<0.05$. Data analysis enabled the identification of three indicator species for ponds located in forest areas, six indicator species for ponds located on agricultural areas (fields), and five for ponds located in villages.

Table 5. IndVal index values for species found in ponds with different land use.

\begin{tabular}{ccccc}
\hline Species & Forest & Field & Village & $p$-Value \\
\hline Ali pla & 0 & 0 & $\mathbf{1 . 2 0}$ & 0.014 \\
Cer dem & 0 & $\mathbf{2 7 . 8 0}$ & 0 & 0.001 \\
Cer sum & 0 & $\mathbf{3 . 8 8}$ & $\mathbf{2 . 1 1}$ & 0.043 \\
Gly flu & $\mathbf{6}$ & 0 & 0 & 0.003 \\
Gly not & 0 & 0 & $\mathbf{1 . 2 2}$ & 0.011 \\
Jun eff & $\mathbf{1 0 . 1 4}$ & 0.18 & 0 & 0.006 \\
Lem min & 6.21 & 0.31 & $\mathbf{1 5 . 6 3}$ & 0.027 \\
Lyc eur & $\mathbf{2 . 5}$ & 0 & 0 & 0.005 \\
Oen aqu & 0 & 0.06 & $\mathbf{4 . 8 4}$ & 0.010 \\
Phr aus & 0 & $\mathbf{2 9 . 7 0}$ & 1.98 & 0.007 \\
Pol hyd & $\mathbf{1 0 . 4 2}$ & 0 & 0 & 0.001 \\
Pot nat & 0 & $\mathbf{1 . 2 4}$ & 0 & 0.013 \\
Typ ang & 0 & $\mathbf{7 . 3 6}$ & 1.00 & 0.007 \\
Typ lat & 0 & $\mathbf{6 . 5 6}$ & 1.50 & 0.008
\end{tabular}

(Ali pla-Alisma plantago-aquatica L.; Cer dem-Ceratophyllum demersum L.; Cer sum-Ceratophyllum submersum L.; Gly flu-Glyceria fluitans (L.) R. Br.; Gly not-Glyceria notata Chevall.; Jun eff-Juncus effusus L.; Lem min-Lemna minor L.; Lyc eur-Lycopus europaeus L.; Oen aqu-Oenanthe aquatica (L.) Poir.; Phr aus-Phragmites australis (Cav.) Trin. ex Steud; Pol hyd-Polygonum hydropiper L.; Pot nat-Potamogeton natans L.; Typ ang-Typha angustifolia L.; Typ lat-Typha latifolia L.). 


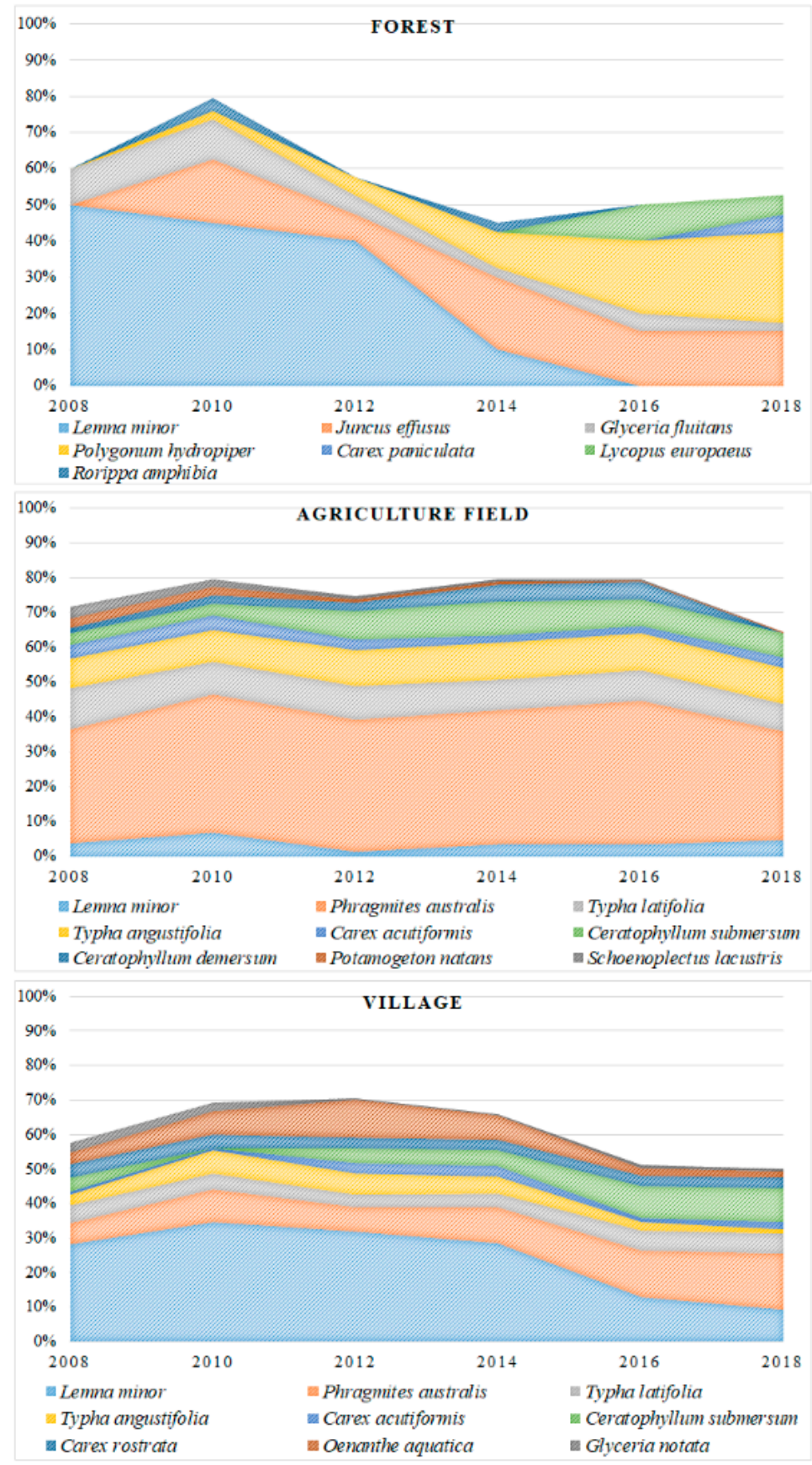

Figure 4. Macrophytes' average percentage coverage of forest, field, and village ponds.

Table 6 presents linear regressions prepared for species during the research period $(p<0.05)$. By far the most expansive species (the ability to exploit all available resources might correspond to the expansion of individual species in natural habitats and represent a criterion for their potential expansiveness) in the studied ponds was Phragmites australis (Cav.) Trin. ex Steud, which increased coverage area significantly in three ponds (out of eight) located in villages and fields. On the other hand, during the research period, the area occupied by Lemna minor L. was reduced in three ponds (out of seven), although it is one of the most common and characteristic species for ponds, indicating their low ecological status and eutrophication [39]. In other cases, single increases or decreases were observed for the area occupied by the species listed in Table 6. Presented trend lines are linear functions 
of the surface change of the species examined over time. $x$-time measured in years. $y$-area occupied by a given species in the total area of pond (expressed in \%).

Table 6. Linear regression for species inhabiting the studied ponds during the research period.

\begin{tabular}{|c|c|c|c|c|c|c|c|}
\hline Species & $\begin{array}{c}\text { Land Use } \\
\text { (Pond Number) }\end{array}$ & Trend Line & $\mathbf{R}^{2}$ & $R^{2}$ adj & SE & F-Value & $p$-Value \\
\hline \multirow{3}{*}{ Lem min } & village (13) & $y=-0.078 x+0.461$ & 0.740 & 0.675 & 0.097 & 11.38 & 0.028 \\
\hline & village (7) & $y=-0.080 x+0.693$ & 0.677 & 0.597 & 0.115 & 8.40 & 0.044 \\
\hline & forest (1) & $y=-0.237 x+1.313$ & 0.904 & 0.880 & 0.161 & 37.78 & 0.003 \\
\hline Gly flu & forest (2) & $y=-0.033 x+0.236$ & 0.712 & 0.640 & 0.044 & 9.88 & 0.035 \\
\hline \multirow{3}{*}{ Phr aus } & field (12) & $y=0.049 x+0.468$ & 0.806 & 0.758 & 0.050 & 16.67 & 0.015 \\
\hline & village (7) & $y=0.055 x-0.103$ & 0.875 & 0.844 & 0.044 & 27.99 & 0.006 \\
\hline & village (6) & $y=0.028 x+0.220$ & 0.707 & 0.634 & 0.038 & 9.66 & 0.036 \\
\hline \multirow{4}{*}{ Typ lat } & village (13) & $y=-0.006 x+0.037$ & 0.658 & 0.574 & 0.009 & 7.73 & 0.049 \\
\hline & field (9) & $y=0.009 x+0.028$ & 0.948 & 0.935 & 0.004 & 73.51 & 0.001 \\
\hline & village (8) & $y=0.022 x+0.038$ & 0.887 & 0.859 & 0.019 & 31.36 & 0.005 \\
\hline & field (5) & $y=-0.024 x+0.363$ & 0.724 & 0.655 & 0.031 & 10.52 & 0.031 \\
\hline Typ ang & field (5) & $y=0.034 x+0.196$ & 0.700 & 0.625 & 0.046 & 9.34 & 0.037 \\
\hline Cer sum & field (10) & $y=0.064 x+0.106$ & 0.675 & 0.594 & 0.093 & 8.32 & 0.045 \\
\hline Pot nat & field (9) & $y=-0.031 x+0.183$ & 0.843 & 0.803 & 0.027 & 21.43 & 0.009 \\
\hline Spa ere & field (9) & $y=0.003 x+0.027$ & 0.697 & 0.622 & 0.004 & 9.23 & 0.038 \\
\hline Pol amp & field (11) & $y=0.019 x-0.025$ & 0.959 & 0.979 & 0.008 & 94.83 & $<0.001$ \\
\hline \multirow{2}{*}{ Sch lac } & village (13) & $y=0.016 x+0.001$ & 0.829 & 0.786 & 0.015 & 19.36 & 0.012 \\
\hline & field (12) & $y=-0.038 x+0.207$ & 0.880 & 0.851 & 0.029 & 29.47 & 0.006 \\
\hline
\end{tabular}

(Lem min—Lemna minor L.; Gly flu—Glyceria fluitans (L.) R. Br.; Phr aus—Phragmites australis (Cav.) Trin. ex Steud; Typ lat-Typha latifolia L.; Typ ang-Typha angustifolia L.; Cer sum-Ceratophyllum submersum L.; Pot nat-Potamogeton natans L.; Spa ere-Sparganium erectum L. emend. Rchb. s. str.; Pol amp-Polygonum amphibium L.; Sch lac-Schoenoplectus lacustris (L.) Palla).

The conducted stepwise regression analysis answered the question as to whether there is a pattern for environmental variables and distribution of macrophytes in time and space. The analysis allowed the preparation of regression models for 15 species tested $-53.57 \%$ of all analyzed species (Table 7).

The variables that most often and most strongly correlated with the species studied were air temperature, $\mathrm{Na}, \mathrm{NH}_{4}{ }^{+}$, and $\mathrm{NO}_{3}{ }^{-}$concentration levels (significant for seven species); $\mathrm{K}$ concentration levels were significant for six species; water temperature and Fe concentration levels were significant for for five species (Tables 8 and A2).

In order to check whether the analyzed variables are related to each other, we performed a Pearson's correlation analysis. On one hand it showed a strong negative correlation between $\mathrm{pH}$ and $\mathrm{Fe}$ and $\mathrm{NO}_{2}{ }^{-}$, and on the other, a positive correlation with $\mathrm{K}$. Very strong positive correlations were observed between $\mathrm{K}$ and $\mathrm{Na}, \mathrm{PO}_{4}{ }^{3-}$ and TP. We also noticed very strong correlations between $\mathrm{Mg}$ and $\mathrm{Ca}$, as well as between $\mathrm{Fe}$ and $\mathrm{NH}_{4}{ }^{+}$(Table 9).

The occurrence of specific macrophyte species were mostly associated with the following variables: the type of pond, its area, and the concentrations of $\mathrm{NH}_{4}{ }^{+}, \mathrm{NO}_{3}{ }^{-}, \mathrm{Na}$, and $\mathrm{Fe}$ (Table 10). Additionally, three plant species were excluded from CCA analysis as outliers. These were: Carex rostrata Stokes (very strongly correlated with $\mathrm{NO}_{3}{ }^{-}$), as well as Rorippa amphibia (L.) Besser and Glyceria fluitans (L.) R. Br. (very strongly correlated with $\mathrm{NH}_{4}{ }^{+}$and $\mathrm{Fe}$ ). Three homogenous groups with similar environmental preferences were identified (Figure 5). 
Table 7. The best regression model for plant species.

\begin{tabular}{|c|c|c|c|c|c|c|c|}
\hline Plant Species & $\begin{array}{l}\text { The Best Regression Models } \\
\text { (D-Determination; \% of Area Occupied by Each Species) }\end{array}$ & $\mathbf{n}$ & $\mathbf{R}^{2}$ & $\mathbf{R}^{2}$ adj. & $\mathrm{SE}_{\mathrm{e}}$ & F-Value & $p$-Value \\
\hline Juncus effusus L. & $\begin{array}{c}\mathrm{D}_{\text {Jun eff }}=-0.011+0.013(\text { air temp. })+0.022(\mathrm{Fe})+0.023\left(\mathrm{NH}_{4}^{+}\right) \\
-0.003\left(\mathrm{NO}_{3}{ }^{-}\right)\end{array}$ & 73 & 0.642 & 0.548 & 0.027 & 6.84 & $<0.001$ \\
\hline Lemna minor $\mathrm{L}$. & $\begin{aligned} \mathrm{D}_{\text {Lem min }}= & -0.138-0.053(\text { air temp. })+0.149(\mathrm{Fe})-0.006(\mathrm{Mg})+ \\
& 0.003(\mathrm{Na})-0.013\left(\mathrm{NO}_{3}{ }^{-}\right)+0.117\left(\mathrm{PO}_{4}{ }^{3-}\right)\end{aligned}$ & 74 & 0.857 & 0.824 & 0.095 & 25.39 & $<0.001$ \\
\hline Lycopus europaeus L. & $\begin{array}{c}\mathrm{D}_{\text {Lyc eur }}=-0.019+0.005(\text { air temp })-0.004(\text { water temp. })+ \\
0.012(\mathrm{Fe})+0.014\left(\mathrm{NH}_{4}^{+}\right)\end{array}$ & 75 & 0.731 & 0.668 & 0.006 & 11.65 & $<0.001$ \\
\hline Polygonum hydropiper L. & $\begin{array}{c}D_{\text {Pol hyd }}=-0.067+0.016(\text { air temp. })-0.013(\text { water temp. })+ \\
0.044(\mathrm{Fe})+0.053\left(\mathrm{NH}_{4}^{+}\right)\end{array}$ & 76 & 0.830 & 0.791 & 0.023 & 21.34 & $<0.001$ \\
\hline Glyceria fluitans (L.) R. Br. & $\begin{array}{c}\left.\left.\mathrm{D}_{\mathrm{Gly} \text { flu }}=0.112+0.008 \text { (air temp. }\right)-0.008 \text { (water temp. }\right)- \\
0.026(\text { depth })+0.010\left(\mathrm{NH}_{4}{ }^{+}\right)\end{array}$ & 75 & 0.516 & 0.404 & 0.014 & 4.58 & $<0.001$ \\
\hline $\begin{array}{l}\text { Glyceria maxima (Hartm.) } \\
\text { Holmb. }\end{array}$ & $\begin{array}{c}\mathrm{D}_{\mathrm{Gly} \max }=0.028+0.001(\text { area })-0.018(\text { depth })-0.001(\mathrm{~K})- \\
0.002\left(\mathrm{NH}_{4}^{+}\right)+0.001\left(\mathrm{NO}_{3}{ }^{-}\right)\end{array}$ & 75 & 0.763 & 0.703 & 0.004 & 12.68 & $<0.001$ \\
\hline $\begin{array}{c}\text { Phragmites australis (Cav.) Trin. } \\
\text { ex Steud }\end{array}$ & $\begin{array}{c}\mathrm{D}_{\text {Phr aus }}=0.019+0.001(\text { area })+0.161(\text { depth })+0.090(\mathrm{pH})- \\
0.002(\mathrm{~K})+0.003(\mathrm{Na})+0.048\left(\mathrm{NH}_{4}^{+}\right)-0.028\left(\mathrm{NO}_{3}{ }^{-}\right)\end{array}$ & 75 & 0.864 & 0.833 & 0.105 & 27.32 & $<0.001$ \\
\hline Carex acutiformis Ehrh. & $\mathrm{D}_{\text {Car acu }}=-0.028-0.001($ area $)+0.023(\mathrm{pH})-0.004(\mathrm{Na})$ & 73 & 0.497 & 0.365 & 0.024 & 3.76 & $<0.001$ \\
\hline Oenanthe aquatica (L.) Poir. & $\begin{array}{c}\mathrm{D}_{\text {Oen aqu }}=0.001-0.001(\mathrm{Ca})+0.001(\mathrm{~K})+0.015(\mathrm{Na}) \\
+0.004\left(\mathrm{NO}_{3}{ }^{-}\right)\end{array}$ & 72 & 0.592 & 0.484 & 0.028 & 5.51 & $<0.001$ \\
\hline Carex rostrata Stokes. & $\mathrm{D}_{\text {Car ros }}=-0.037+0.012\left(\mathrm{NO}_{3}{ }^{-}\right)$ & 73 & 0.681 & 0.596 & 0.022 & 8.09 & $<0.001$ \\
\hline Typha latifolia $\mathrm{L}$. & $\begin{array}{c}\mathrm{D}_{\text {Typ lat }}=0.159-0.048(\text { air temp. })+0.035(\text { water temp. })- \\
0.023(\mathrm{Fe})+0.002(\mathrm{~K})+0.001(\mathrm{Na})\end{array}$ & 74 & 0.678 & 0.595 & 0.050 & 8.15 & $<0.001$ \\
\hline Typha angustifolia L. & $\begin{array}{c}\mathrm{D}_{\text {Typ ang }}=0.212+0.125(\text { depth })+0.001(\mathrm{~K})+0.002(\mathrm{Na}) \\
+0.015\left(\mathrm{NO}_{3}{ }^{-}\right)\end{array}$ & 75 & 0.494 & 0.366 & 0.084 & 3.84 & $<0.001$ \\
\hline Alisma plantago-aquatica L. & $\mathrm{D}_{\text {Ali pla }}=-0.016-0.020($ depth $)+0.002(\mathrm{~K})$ & 74 & 0.438 & 0.302 & 0.016 & 3.22 & $<0.001$ \\
\hline Rumex palustris $\mathrm{Sm}$. & $\begin{array}{c}\mathrm{D}_{\text {Rum pal }}=0.002+0.002 \text { (air temp.) }-0.002 \text { (water temp.) } \\
+0.001(\mathrm{Na})\end{array}$ & 73 & 0.429 & 0.291 & 0.004 & 3.11 & $<0.001$ \\
\hline Schoenoplectus lacustris (L.) Palla & $\mathrm{D}_{\text {Sch lac }}=-0.169+0.001($ area $)+0.027(\mathrm{pH})$ & 76 & 0.446 & 0.312 & 0.026 & 3.33 & $<0.001$ \\
\hline
\end{tabular}


Table 8. Pearson's correlations between distribution of macrophyte species and the variables studied.

\begin{tabular}{|c|c|c|c|c|c|c|c|c|c|c|c|c|c|}
\hline $\begin{array}{l}\% \text { of Area } \\
\text { Occupied by } \\
\text { the Species }\end{array}$ & $\begin{array}{c}\text { Air } \\
\text { Temp. }\end{array}$ & $\begin{array}{l}\text { Water } \\
\text { Temp. }\end{array}$ & Area & Depth & $\mathrm{pH}$ & $\mathbf{F e}$ & $\mathrm{Ca}$ & $\mathrm{Mg}$ & $\mathbf{K}$ & $\mathrm{Na}$ & $\mathrm{NH}_{4}{ }^{+}$ & $\mathrm{NO}_{3}{ }^{-}$ & $\mathrm{PO}_{4}{ }^{3-}$ \\
\hline Ali pla & 0.104 & 0.255 & -0.261 & -0.357 & -0.114 & -0.034 & -0.144 & 0.117 & 0.481 & 0.318 & 0.076 & -0.134 & 0.205 \\
\hline Car acu & 0.077 & -0.024 & -0.369 & 0.199 & 0.305 & -0.170 & 0.165 & 0.021 & -0.182 & -0.069 & -0.275 & 0.246 & -0.156 \\
\hline Car ros & 0.070 & -0.153 & -0.016 & 0.200 & 0.049 & -0.004 & 0.277 & 0.101 & -0.204 & -0.064 & -0.172 & 0.769 & -0.187 \\
\hline Gly flu & 0.342 & -0.452 & -0.130 & -0.370 & -0.250 & 0.195 & -0.208 & -0.188 & -0.188 & -0.222 & 0.241 & -0.133 & -0.164 \\
\hline Gly max & 0.021 & -0.022 & 0.290 & -0.213 & 0.194 & -0.035 & 0.100 & 0.077 & -0.357 & 0.169 & -0.294 & 0.217 & 0.248 \\
\hline Jun eff & 0.301 & -0.150 & -0.243 & -0.214 & -0.263 & 0.326 & -0.289 & -0.280 & -0.220 & -0.283 & 0.533 & -0.352 & -0.183 \\
\hline Lem $\min$ & -0.338 & 0.048 & -0.200 & -0.270 & -0.023 & 0.501 & -0.211 & -0.346 & 0.224 & 0.470 & 0.435 & -0.386 & 0.372 \\
\hline Lyc eur & 0.332 & -0.327 & -0.171 & -0.161 & -0.194 & 0.325 & -0.163 & -0.138 & -0.060 & -0.171 & 0.507 & -0.054 & -0.041 \\
\hline Oen aqu & -0.001 & 0.145 & -0.195 & -0.104 & 0.112 & -0.109 & -0.218 & -0.005 & 0.346 & 0.514 & -0.129 & 0.309 & 0.022 \\
\hline Phr aus & -0.049 & 0.074 & 0.826 & 0.379 & 0.250 & -0.280 & 0.250 & 0.296 & -0.324 & 0.297 & 0.330 & -0.254 & 0.176 \\
\hline Pol hyd & 0.460 & -0.456 & -0.238 & -0.193 & -0.226 & 0.327 & -0.233 & -0.203 & -0.088 & -0.216 & 0.651 & -0.073 & -0.060 \\
\hline Rum pal & 0.319 & -0.352 & -0.198 & -0.134 & 0.157 & -0.041 & -0.125 & 0.009 & 0.283 & 0.434 & -0.065 & -0.121 & 0.050 \\
\hline Sch lac & -0.011 & 0.187 & 0.427 & -0.023 & 0.337 & -0.180 & 0.169 & 0.116 & -0.104 & 0.011 & -0.165 & -0.145 & -0.074 \\
\hline Typ ang & -0.035 & 0.213 & 0.184 & 0.332 & -0.042 & -0.164 & 0.120 & 0.013 & 0.254 & 0.337 & -0.054 & 0.372 & 0.138 \\
\hline Typ lat & -0.332 & 0.415 & -0.096 & -0.157 & -0.180 & -0.343 & 0.010 & 0.105 & 0.274 & 0.400 & -0.093 & -0.039 & -0.083 \\
\hline
\end{tabular}

Significant correlation at 0.001 level in bold; (Ali pla-Alisma plantago-aquatica L.; Car acu-Carex acutiformis L.; Car ros-Carex rostrata Stokes; Gly flu—Glyceria fluitans (L.) R. Br.; Gly max-Glyceria maxima (Hartm.) Holmb.; Jun eff-Juncus effusus L.; Lem min—Lemna minor L.; Lyc eur-Lycopus europaeus L.; Oen aqu—Oenanthe aquatica (L.) Poir.; Phr aus—Phragmites australis (Cav.) Trin. ex Steud; Pol hyd—Polygonum hydropiper L.; Rum pal—Rumex palustris Sm.; Sch lac-Schoenoplectus lacustris (L.) Palla; Typ ang—Typha angustifolia L.; Typ lat—Typha latifolia L.) 
Table 9. Pearson's correlation for the analyzed variables.

\begin{tabular}{|c|c|c|c|c|c|c|c|c|c|c|c|c|c|c|c|c|}
\hline Variable & Rainfall & $\begin{array}{c}\text { Air } \\
\text { Temp. }\end{array}$ & $\begin{array}{l}\text { Water } \\
\text { Temp. }\end{array}$ & Area & Depth & $\mathrm{pH}$ & $\mathrm{Fe}$ & $\mathrm{Ca}$ & $\mathrm{Mg}$ & $\mathbf{K}$ & $\mathrm{Na}$ & $\mathrm{NH}_{4}{ }^{+}$ & $\mathrm{NO}_{2}^{-}$ & $\mathrm{NO}_{3}{ }^{-}$ & $\mathrm{PO}_{4}{ }^{3-}$ & TP \\
\hline Rainfall & 1 & & & & & & & & & & & & & & & \\
\hline Air Temp. & -0.53 & 1 & & & & & & & & & & & & & & \\
\hline Water Temp. & -0.39 & 0.60 & 1 & & & & & & & & & & & & & \\
\hline Area & 0.06 & -0.08 & 0.06 & 1 & & & & & & & & & & & & \\
\hline Depth & 0.06 & -0.08 & -0.33 & 0.40 & 1 & & & & & & & & & & & \\
\hline $\mathrm{pH}$ & 0.06 & -0.05 & 0.24 & 0.31 & 0.39 & 1 & & & & & & & & & & \\
\hline $\mathrm{Fe}$ & -0.08 & 0.04 & -0.31 & -0.39 & -0.23 & -0.54 & 1 & & & & & & & & & \\
\hline $\mathrm{Ca}$ & -0.16 & 0.27 & 0.34 & 0.44 & 0.32 & 0.47 & -0.37 & 1 & & & & & & & & \\
\hline Mg & -0.21 & 0.39 & 0.43 & 0.33 & 0.18 & 0.36 & -0.28 & 0.59 & 1 & & & & & & & \\
\hline$K$ & 0.00 & 0.01 & 0.31 & -0.24 & -0.14 & 0.26 & -0.13 & -0.14 & 0.14 & 1 & & & & & & \\
\hline $\mathrm{Na}$ & 0.03 & -0.05 & 0.40 & -0.15 & -0.02 & 0.60 & -0.40 & 0.10 & 0.28 & 0.79 & 1 & & & & & \\
\hline $\mathrm{NH}_{4}{ }^{+}$ & 0.07 & -0.01 & -0.21 & -0.44 & -0.40 & -0.44 & 0.72 & -0.45 & -0.32 & 0.13 & -0.21 & 1 & & & & \\
\hline $\mathrm{NO}_{2}^{-}$ & 0.11 & 0.03 & -0.08 & -0.35 & 0.12 & -0.56 & 0.14 & 0.02 & 0.02 & -0.20 & -0.23 & 0.48 & 1 & & & \\
\hline $\mathrm{NO}_{3}^{-}$ & 0.10 & -0.04 & -0.14 & 0.02 & 0.18 & 0.09 & -0.10 & 0.46 & 0.14 & -0.41 & -0.13 & -0.26 & 0.29 & 1 & & \\
\hline $\mathrm{PO}_{4}{ }^{3-}$ & 0.09 & -0.05 & 0.07 & -0.03 & 0.21 & 0.45 & -0.14 & -0.01 & 0.10 & 0.80 & 0.58 & 0.15 & -0.05 & -0.37 & 1 & \\
\hline \multirow[t]{2}{*}{ TP } & 0.07 & -0.03 & 0.08 & -0.01 & 0.21 & 0.46 & -0.14 & 0.01 & 0.15 & 0.79 & 0.58 & 0.14 & -0.19 & -0.37 & 0.99 & 1 \\
\hline & & & & & & & & & $\begin{array}{l}\text { cor } \\
\text { cor }\end{array}$ & & & & & & & \\
\hline
\end{tabular}


Table 10. Statistical parameters for the CCA analysis (E\%-the explanation percent, $p$-statistical significance, $\mathrm{F}$ - the result of the analysis of variance).

\begin{tabular}{cccc}
\hline Variable & $\mathbf{E} \%$ & $p$ & $\mathbf{F}$ \\
\hline field & 11.06 & 0.001 & 17.52 \\
forest & 9.77 & 0.001 & 16.69 \\
village & 9.12 & 0.001 & 16.21 \\
$\mathrm{~K}$ & 8.74 & 0.001 & 15.42 \\
$\mathrm{Na}$ & 8.51 & 0.001 & 14.99 \\
$\mathrm{NH}_{4}{ }^{+}$ & 7.69 & 0.002 & 13.72 \\
area $_{\mathrm{TP}}$ & 7.42 & 0.002 & 10.56 \\
$\mathrm{pH}$ & 7.01 & 0.004 & 9.24 \\
$\mathrm{Fe}$ & 6.32 & 0.008 & 8.23 \\
$\mathrm{NO}_{3}{ }^{-}$ & 6.00 & 0.011 & 6.33 \\
depth $_{\text {ice }}^{5.21}$ & 0.019 & 5.43 \\
i. & 5.19 & 0.037 & 2.35 \\
\hline
\end{tabular}

Number of variables included: 18; number of variables rejected: 5; number of permutations: 9999.

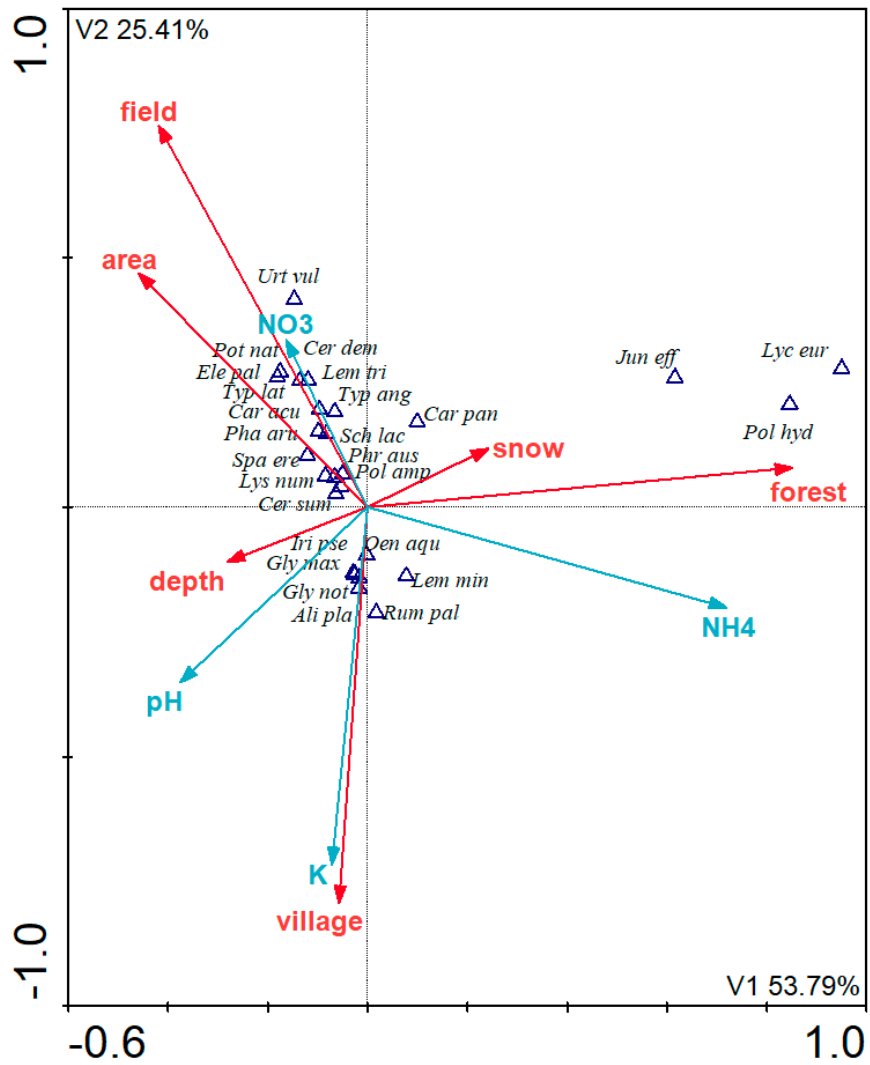

Figure 5. CCA analysis $(\mathrm{n}=234)$ depicting the dependence between the macrophytes (Ali pla-Alisma plantago-aquatica L.; Car acu-Carex acutiformis L.; Car pan-Carex paniculata L.; Car ros-Carex rostrata Stokes; Cer dem-Ceratophyllum demersum L.; Cer sum-Ceratophyllum submersum L.; Ele pal-Eleocharis palustris (L. Roem. \& Schult.); Gly flu—Glyceria fluitans (L.) R. Br.; Gly max-Glyceria maxima (Hartm.) Holmb.; Gly not—Glyceria notata Chevall.; Iri pse-Iris pseudacorus L.; Jun eff-Juncus effusus L.; Lem min—Lemna minor L.; Lem tri-Lemna trisulca L.; Lyc eur-Lycopus europaeus L.; Lys num-Lysimachia nummularia L.; Oen aqu-Oenanthe aquatica (L.) Poir.; Pha aru-Phalaris arundinacea L.; Phr aus-Phragmites australis (Cav.) Trin. ex Steud; Pol amp-Polygonum amphibium L.; Pol hyd-Polygonum hydropiper L.; Pot nat-Potamogeton natans L.; Ror amp—Rorippa amphibia (L.) Besser; Rum pal-Rumex palustris Sm.; Sch lac—Schoenoplectus lacustris (L.) Palla; Spa ere-Sparganium erectum L. emend. Rchb. s. str.; Typ ang-Typha angustifolia L.; Typ lat-Typha latifolia L.; Urt vul-Utricularia vulgaris L.) and environmental/physicochemical variables. 


\section{Discussion}

So far studies on vegetation in ponds have mostly focused on their floristic composition and the phytocoenosis structure. However, little is known about the relation between these plant communities and their habitats (physical and chemical properties of water and soil). Studies on lakes proved the noticeable dependency between plant communities and specific habitat parameters [40-42]. Finding the correlation between the macrophyte diversity and the method of land use in the areas surrounding ponds is necessary not only to understand the mechanisms of maintaining macrophyte diversity but also to provide important information which will help to maintain biodiversity [25].

In comparison with lakes and other larger freshwater bodies, there was a higher share of reed and pleustophyte communities (Phragmitetea and Lemnetea classes) and a smaller share of communities belonging to the Potametea group among the vegetation in ponds. However, there was a typical feature of aquatic vegetation-one dominant species in phytocoenoses $[43,44]$. Our research findings confirmed this observation.

Existing studies also observed considerable fluctuations in the water level in ponds located in fields and emphasized that this feature distinguished ponds from larger and more stable ecosystems [27,41]. Studies conducted all over the world revealed a positive correlation between the small size and low depth of ponds. On one hand, this may result in better light conditions for macrophytes and stimulate their growth [45]. On the other hand, ponds located in fields are more likely to dry out during the summer $[46,47]$. The variation in water level had a certain influence on the growth of macrophytes [48,49]. Those findings were consistent with the results obtained by Wang et al. [50]. Our research did not confirm the above data for all species we studied. Our research and analysis allowed us to conclude a statistically significant positive correlation between the depth of ponds and the growth of Phragmites australis (Cav.) Trin. ex Steud and Typha angustifolia L., and a statistically significant negative correlation between depth and growth of Glyceria fluitans (L.) R. Br., Glyceria maxima (Hartm.) Holmb., and Alisma plantago-aquatica L. Research conducted in the Mediterranean and semi-arid areas proved that droughts may cause lower water levels and even temporal total disappearance of ponds located in fields [51]. Our research and analyses did not let us conclude that ponds are in danger of shallowing.

Existing studies found that the growth of macrophytes had a significant correlation with air temperature [52,53]. For example, the rise in annual average air temperature can promote continuous growth of macrophytes. This finding was consistent with the conclusions obtained by Wang et al. [50]. Our studies in the ten-year period showed that a statistically significant positive correlation between air temperature and macrophyte growth concerns only a few species: Juncus effusus L., Lycopus europaeus L., Polygonum hydropiper L., Glyceria fluitans (L.) R. Br., and Rumex palustris Sm. We have also found a statistically significant negative correlation between air temperature and macrophyte growth in the case of Lemna minor L. and Typha latifolia L. Our studies also showed a statistically significant positive correlation between water temperature and macrophyte development of Typha latifolia L., and a statistically significant negative correlation between water temperature and macrophyte development for Lycopus europaeus L., Polygonum hydropiper L., Glyceria fluitans (L.) R. Br., and Rumex palustris Sm.

The physicochemical status of water, which largely controls the biodiversity of macrophytes, is affected by the land use method around a pond [8,54-56]. Research results show that the quality of water in ponds located in the catchment area covered by forests was better than the quality of water in the catchment area where land was used differently [57-59]. The analysis of the water samples collected during our ten-year research period showed that the water from the forest ponds had the lowest $\mathrm{pH}$ as well as the lowest $\mathrm{Ca}, \mathrm{Na}$, and $\mathrm{Mg}$ concentrations. On one hand, the samples of water from these ponds contained more Fe and $\mathrm{NH}_{4}{ }^{+}$than the water from the other ponds. An increase of $\mathrm{NH}_{4}{ }^{+}$may be caused either by greater decomposition or anoxia (which can be very harmful for many species) [60] or by lack of macrophyte species in ponds [61]. On the other hand, forests reduce surface runoff of nutrients and increase the filtration and interception of these compounds in catchment areas [62]. Existing studies showed that the distribution area variation had a significant positive 
correlation with $\mathrm{NH}_{4}{ }^{+}$concentration [63], which was different from Wang et al.'s [50] study. The results of our studies indicate that a statistically significant positive correlation between the occurrence of macrophytes and the content of $\mathrm{NH}_{4}{ }^{+}$in water occurs only in the case of ponds located in forest areas. In the case of ponds in the fields, we found a positive correlation between the occurrence of macrophytes and the content of $\mathrm{NO}_{3}{ }^{-}$. In the case of villages, we found a positive correlation between the occurrence of macrophytes and the content of $\mathrm{K}, \mathrm{Na}$, and total P. N and P are key elements for the existence and health of macrophyte communities, but an excessive load of nutrients may result in eutrophication [64]. Research conducted on ponds in Patagonia showed that the concentrations of nutrients were good indicators of the state and quality of water. The content of nutrients in ponds affected by sewage should be higher than in more isolated ponds [65].

Researchers studied the correlation between the species abundance of flora and fauna and the land use in the areas surrounding ponds [66,67]. Our analyses confirmed the correlation between the flora species and land use type.

\section{Conclusions}

(1) We have found a combination of macrophytes associated with each type of land use. Juncus effusus L., Glyceria fluitans (L.) R. Br., Polygonum hydropiper L., and Lycopus europaeus L. were associated with forest ponds. Phragmites australis (Cav.) Trin. ex Steud, Typha angustifolia L., Typha latifolia L., Ceratophyllum demersum L., and Potamogeton natans L. were associated with agriculture field ponds. Lemna minor L., Oenanthe aquatica (L.) Poir., Glyceria notata Chevall., and Alisma plantago-aquatica L were associated with village ponds;

(2) We have found a combination of water chemical parameters associated with each land use. Much higher levels of $\mathrm{K}, \mathrm{Na}$, and TP concentrations were present in the water of village ponds. Higher levels of $\mathrm{NO}_{3}{ }^{-}$concentration were observed in the water of village and agriculture field ponds. On one hand, low $\mathrm{Ca}, \mathrm{Na}$ and $\mathrm{Mg}$ concentrations and the lowest $\mathrm{pH}$ values were observed in the waters of forest ponds, which on the other hand were characterized by higher levels of $\mathrm{NH}_{4}{ }^{+}$and Fe concentrations;

(3) The stepwise regression analysis showed the variables that correlate the temporal macrophytes distribution are air and water temperature as well as $\mathrm{Na}, \mathrm{NH}_{4}{ }^{+}, \mathrm{NO}_{3}{ }^{-}, \mathrm{K}$, and Fe concentration in water;

(4) By creating the CCA analysis, we can associate greater variety of macrophyte species with deeper and bigger agriculture field ponds compared to other ponds;

(5) During the research period the expansion of Phragmites australis (Cav.) Trin. ex Steud was observed. In the same time, we have observed a reduction in the area occupied by Lemna minor L.;

(6) Ponds located in villages seem to be the most vulnerable to anthropopressure. Forest ponds have, however, been rated the best in terms of landscape variables.

Author Contributions: Conceptualization, D.Ś. and M.K.; data curation, D.Ś.; formal analysis, D.Ś.; investigation, D.Ś. and M.K.; methodology, D.Ś. and M.K.; project administration, D.Ś. and M.K.; resources, D.Ś.; supervision, D.Ś; validation, D.Ś.; visualization, D.Ś. and M.K.; writing—original draft preparation, D.Ś. and M.K.; writing—review and editing, D.Ś. and M.K.; supervision, M.K.; project administration, D.Ś; funding acquisition, D.Ś.

Funding: This research was supported by the Polish Ministry of Science and Higher Education as part of statutory activities.

Acknowledgments: We would like to thank Anna Budka (Department of Mathematical and Statistical Methods, Poznań University of Life Sciences) for validating statistical methods used in the paper.

Conflicts of Interest: The authors declare no conflict of interest. The funders had no role in the design of the study; in the collection, analyses, or interpretation of data; in the writing of the manuscript, or in the decision to publish the results. 


\section{Appendix A}

Table A1. The values of optimisation parameters in the Flame Atomic Absorption Spectrometry (F-AAS) and Atomic Emission Spectrometry (AES) methods.

\begin{tabular}{cccccc}
\hline \multirow{2}{*}{ Optimisation Parameters } & \multicolumn{3}{c}{ F-AAS } & \multicolumn{3}{c}{ AES } \\
\cline { 2 - 6 } & Ca & $\mathbf{M g}$ & $\mathbf{F e}$ & $\mathbf{N a}$ & $\mathbf{K}$ \\
\hline lamp current (mA) & 10 & 6 & 30 & - & - \\
wavelength (nm) & 422.67 & 285.21 & 248.33 & 589.00 & 766.49 \\
gap (nm) & $2.7 / 0.6$ & $2.7 / 1.05$ & $1.8 / 1.35$ & $1.8 / 0.6$ & $1.8 / 0.6$ \\
oxidising gas (air) flow (L/m) & 10.00 & 10.00 & 10.00 & 10.00 & 10.00 \\
flammable gas (acetylene) flow (L/m) & 2.70 & 2.50 & 2.50 & 2.50 & 2.50 \\
integration time (s) & 3.0 & 3.0 & 3.0 & 3.0 & 3.0 \\
readout time (s) & 5.0 & 5.0 & 5.0 & 5.0 & 5.0 \\
\hline
\end{tabular}

Table A2. The physicochemical parameters of the water in ponds.

\begin{tabular}{|c|c|c|c|c|c|c|c|c|c|c|c|c|c|c|}
\hline \multirow{2}{*}{ Variable } & & \multicolumn{2}{|c|}{ Forest } & \multicolumn{6}{|c|}{ Field } & \multicolumn{5}{|c|}{ Village } \\
\hline & & 1 & 2 & 3 & 5 & 9 & 10 & 11 & 12 & 4 & 6 & 7 & 8 & 13 \\
\hline \multirow{4}{*}{$\begin{array}{l}\text { water temp. } \\
\qquad\left(\mathrm{C}^{\circ}\right)\end{array}$} & $\min$ & 8.97 & 8.88 & 9.44 & 9.97 & 10.01 & 9.66 & 8.21 & 10.51 & 8.94 & 10.11 & 10.57 & 10.37 & 9.22 \\
\hline & $\max$ & 10.21 & 10.47 & 11.31 & 13.21 & 12.66 & 12.51 & 11.61 & 13.91 & 11.47 & 13.07 & 13.47 & 12.48 & 12.41 \\
\hline & mean & 9.53 & 9.51 & 10.44 & 10.99 & 11.36 & 10.92 & 10.05 & 12.23 & 9.87 & 11.01 & 11.94 & 11.52 & 10.71 \\
\hline & SD & 0.44 & 0.64 & 0.74 & 1.21 & 1.02 & 1.12 & 1.19 & 1.22 & 0.95 & 1.18 & 1.17 & 0.90 & 1.11 \\
\hline \multirow{4}{*}{$\mathrm{pH}$} & $\min$ & 4.99 & 4.83 & 6.21 & 5.03 & 6.72 & 6.91 & 6.95 & 7.41 & 6.87 & 7.32 & 6.23 & 7.21 & 8.25 \\
\hline & $\max$ & 5.74 & 5.60 & 6.87 & 6.01 & 7.21 & 7.88 & 7.82 & 7.67 & 7.21 & 8.61 & 6.80 & 7.96 & 8.66 \\
\hline & mean & 5.29 & 5.23 & 6.46 & 5.51 & 6.91 & 7.25 & 7.40 & 7.55 & 7.02 & 7.94 & 6.50 & 7.58 & 8.38 \\
\hline & SD & 0.29 & 0.32 & 0.24 & 0.38 & 0.18 & 0.36 & 0.32 & 0.12 & 0.15 & 0.48 & 0.24 & 0.24 & 0.15 \\
\hline \multirow{4}{*}{$\mathrm{Fe}\left(\mathrm{mg} \mathrm{L}^{-1}\right)$} & $\min$ & 1.23 & 0.72 & 0.27 & 0.12 & 0.12 & 0.10 & 0.15 & 0.02 & 0.21 & 0.23 & 0.21 & 0.31 & 0.04 \\
\hline & $\max$ & 7.26 & 2.45 & 0.67 & 0.95 & 0.47 & 0.42 & 0.53 & 0.11 & 1.25 & 0.82 & 1.12 & 0.62 & 0.15 \\
\hline & mean & 3.73 & 1.63 & 0.48 & 0.43 & 0.31 & 0.27 & 0.29 & 0.07 & 0.73 & 0.49 & 0.50 & 0.42 & 0.10 \\
\hline & SD & 2.45 & 0.73 & 0.17 & 0.28 & 0.13 & 0.14 & 0.14 & 0.04 & 0.46 & 0.21 & 0.33 & 0.10 & 0.04 \\
\hline \multirow{4}{*}{$\mathrm{Ca}\left(\mathrm{mg} \mathrm{L}^{-1}\right)$} & $\min$ & 1.26 & 1.21 & 33.12 & 29.14 & 39.26 & 32.31 & 21.09 & 39.10 & 38.11 & 31.30 & 22.15 & 17.04 & 36.02 \\
\hline & $\max$ & 4.07 & 5.28 & 87.23 & 38.20 & 121.04 & 137.05 & 113.17 & 110.44 & 126.20 & 92.17 & 42.04 & 40.13 & 81.14 \\
\hline & mean & 2.24 & 3.02 & 49.21 & 33.37 & 75.67 & 69.67 & 66.83 & 74.67 & 85.17 & 62.28 & 30.88 & 24.33 & 51.67 \\
\hline & SD & 1.08 & 1.37 & 21.66 & 3.98 & 32.17 & 45.24 & 38.38 & 24.51 & 35.37 & 21.56 & 8.26 & 8.14 & 17.31 \\
\hline \multirow{4}{*}{$\mathrm{Mg}\left(\mathrm{mg} \mathrm{L}^{-1}\right)$} & $\min$ & 0.87 & 0.32 & 2.13 & 2.02 & 3.41 & 3.23 & 6.04 & 3.21 & 3.15 & 3.24 & 4.21 & 2.32 & 3.81 \\
\hline & $\max$ & 1.33 & 0.99 & 17.82 & 12.12 & 18.01 & 17.03 & 17.22 & 25.19 & 20.20 & 20.12 & 22.17 & 15.41 & 9.20 \\
\hline & mean & 1.07 & 0.71 & 11.76 & 5.35 & 9.65 & 8.87 & 11.02 & 13.32 & 11.10 & 11.12 & 9.92 & 8.98 & 5.03 \\
\hline & $\mathrm{SD}$ & 0.18 & 0.24 & 5.39 & 3.69 & 5.55 & 5.36 & 4.35 & 9.40 & 6.46 & 6.27 & 6.43 & 4.62 & 2.12 \\
\hline \multirow{4}{*}{$\mathrm{K}\left(\mathrm{mg} \mathrm{L}^{-1}\right)$} & $\min$ & 39.12 & 20.11 & 21.12 & 75.32 & 39.31 & 20.13 & 69.12 & 33.21 & 29.12 & 171.01 & 187.03 & 152.09 & 61.01 \\
\hline & $\max$ & 66.12 & 35.15 & 39.16 & 103.24 & 45.02 & 37.41 & 99.65 & 55.24 & 34.25 & 190.32 & 215.41 & 175.52 & 81.40 \\
\hline & mean & 50.03 & 29.91 & 29.82 & 85.87 & 41.33 & 27.00 & 83.50 & 43.33 & 31.97 & 180.22 & 202.33 & 161.50 & 73.33 \\
\hline & $\mathrm{SD}$ & 9.26 & 5.29 & 6.27 & 10.17 & 2.25 & 5.76 & 10.25 & 7.55 & 1.94 & 8.21 & 12.09 & 8.92 & 7.34 \\
\hline \multirow{4}{*}{$\mathrm{Na}\left(\mathrm{mg} \mathrm{L}^{-1}\right)$} & $\min$ & 7.13 & 8.33 & 42.17 & 38.27 & 73.47 & 76.13 & 80.77 & 73.37 & 62.11 & 126.02 & 157.03 & 203.21 & 96.00 \\
\hline & $\max$ & 27.11 & 12.37 & 62.11 & 60.22 & 82.30 & 84.62 & 101.09 & 86.42 & 90.23 & 152.54 & 203.12 & 247.50 & 111.04 \\
\hline & mean & 13.42 & 10.09 & 55.57 & 46.68 & 78.50 & 80.67 & 87.33 & 81.00 & 76.57 & 137.67 & 176.33 & 220.00 & 102.50 \\
\hline & $\mathrm{SD}$ & 7.37 & 1.62 & 7.24 & 10.14 & 3.39 & 2.94 & 7.66 & 4.56 & 10.64 & 9.27 & 16.42 & 15.52 & 5.79 \\
\hline \multirow{4}{*}{$\mathrm{NH}_{4}^{+}\left(\mathrm{mg} \mathrm{L}^{-1}\right)$} & $\min$ & 6.52 & 1.36 & 0.70 & 1.09 & 1.00 & 0.88 & 0.85 & 0.7 & 0.45 & 1.75 & 1.79 & 0.95 & 0.52 \\
\hline & $\max$ & 7.36 & 1.83 & 0.96 & 1.62 & 1.62 & 1.34 & 1.36 & 1.50 & 0.71 & 3.11 & 2.93 & 2.10 & 0.93 \\
\hline & mean & 7.08 & 1.54 & 0.80 & 1.38 & 1.28 & 1.13 & 1.10 & 1.11 & 0.59 & 2.53 & 2.42 & 1.49 & 0.72 \\
\hline & $\mathrm{SD}$ & 0.30 & 0.16 & 0.11 & 0.20 & 0.24 & 0.17 & 0.18 & 0.24 & 0.10 & 0.48 & 0.37 & 0.39 & 0.15 \\
\hline \multirow{4}{*}{$\begin{array}{l}\text { nitrate nitrogen } \\
\qquad\left(\mathrm{mg} \mathrm{L}^{-1}\right)\end{array}$} & $\min$ & 0.9 & 0.63 & 0.55 & 0.59 & 5.26 & 4.26 & 1.28 & 1.42 & 6.59 & 0.51 & 0.63 & 0.41 & 0.42 \\
\hline & $\max$ & 1.26 & 0.75 & 0.79 & 2.16 & 7.59 & 6.56 & 1.76 & 1.72 & 12.36 & 0.88 & 1.12 & 0.99 & 0.71 \\
\hline & mean & 1.05 & 0.72 & 0.65 & 1.59 & 6.09 & 5.51 & 1.41 & 1.53 & 9.98 & 0.74 & 0.84 & 0.69 & 0.59 \\
\hline & SD & 0.14 & 0.05 & 0.09 & 0.54 & 0.84 & 0.84 & 0.18 & 0.11 & 2.20 & 0.14 & 0.19 & 0.19 & 0.11 \\
\hline \multirow{4}{*}{$\mathrm{TP}\left(\mathrm{mg} \mathrm{L}^{-1}\right)$} & $\min$ & 0.69 & 0.13 & 0.07 & 0.16 & 0.06 & 0.35 & 2.36 & 0.02 & 0.06 & 4.89 & 2.35 & 1.69 & 1.65 \\
\hline & $\max$ & 0.91 & 0.16 & 0.09 & 0.42 & 0.13 & 0.59 & 3.98 & 0.09 & 0.12 & 7.36 & 4.36 & 2.52 & 2.69 \\
\hline & mean & 0.79 & 0.15 & 0.09 & 0.30 & 0.11 & 0.45 & 3.24 & 0.07 & 0.08 & 6.55 & 3.54 & 2.23 & 2.22 \\
\hline & SD & 0.08 & 0.01 & 0.01 & 0.10 & 0.02 & 0.08 & 0.55 & 0.03 & 0.02 & 1.03 & 0.93 & 0.30 & 0.41 \\
\hline \multirow{4}{*}{$\begin{array}{l}\text { phosphate } \\
\text { phosphorus } \\
\left(\mathrm{mg} \mathrm{L}^{-1}\right)\end{array}$} & $\min$ & 0.21 & 0.04 & 0.02 & 0.06 & 0.02 & 0.10 & 0.85 & 0.01 & 0.00 & 1.89 & 0.93 & 0.52 & 0.61 \\
\hline & $\max$ & 0.29 & 0.06 & 0.05 & 0.12 & 0.05 & 0.25 & 1.42 & 0.28 & 0.05 & 2.71 & 1.41 & 0.89 & 1.03 \\
\hline & mean & 0.25 & 0.05 & 0.04 & 0.10 & 0.04 & 0.16 & 1.14 & 0.10 & 0.03 & 2.32 & 1.20 & 0.77 & 0.76 \\
\hline & SD & 0.03 & 0.01 & 0.01 & 0.03 & 0.01 & 0.06 & 0.22 & 0.11 & 0.02 & 0.34 & 0.19 & 0.13 & 0.18 \\
\hline
\end{tabular}




\section{References}

1. Hill, M.J.; Ryves, D.B.; White, J.C.; Wood, P.J. Macroinvertebrate diversity in urban and rural ponds: Implications for freshwater biodiversity conservation. Biol. Conserv. 2016, 201, 50-59. [CrossRef]

2. Céréghino, R.; Boix, D.; Cauchie, H.M.; Martens, K.; Oertli, B. The ecological role of ponds in a changing world. Hydrobiologia 2014, 723, 1-6. [CrossRef]

3. Lukács, B.A.; Sramkó, G.; Molnár, A. Plant diversity and conservation value of continental temporary pools. Biol. Conserv. 2013, 158, 393-400. [CrossRef]

4. Vad, C.F.; Péntek, A.L.; Cozma, N.J.; Földi, A.; Tóth, A.; Tóth, B.; Böde, N.A.; Móra, A.; Ptacnik, R.; Ács, É.; et al. Wartime scars or reservoirs of biodiversity? The value of bomb crater ponds in aquatic conservation. Biol. Conserv. 2017, 209, 253-262. [CrossRef] [PubMed]

5. Oertli, B.; Joye, D.A.; Castella, E.; Juge, R.; Cambin, D.; Lachavanne, J.B. Does size matter? The relationship between pond area and biodiversity. Biol. Conserv. 2002, 104, 59-70. [CrossRef]

6. Oertli, B.; Céréghino, R.; Hull, A.; Miracle, R. Pond conservation: From science to practice. Hydrobiologia 2009, 634, 1-9. [CrossRef]

7. Thiere, G.; Milenkovski, S.; Lindgren, P.E.; Sahlén, G.; Berglund, O.; Weisner, S.E.B. Wetland creation in agricultural landscapes: Biodiversity benefits on local and regional scales. Biol. Conserv. 2009, 142, 964-973. [CrossRef]

8. Declerck, S.; De Bie, T.; Ercken, D.; Hampel, H.; Schrijvers, S.; Van Wichelen, J.; Gillard, V.; Mandiki, R.; Losson, B.; Bauwens, D.; et al. Ecological characteristics of small farmland ponds: Associations with land use practices at multiple spatial scales. Biol. Conserv. 2006, 131, 523-532. [CrossRef]

9. Perotti, M.G.; Diéguez, M.C.; Jara, F.G. Estado del conocimiento de humedales del norte patagónico (Argentina): Aspectos relevantes e importancia para la conservación de la biodiversidad regional. Rev. Chil. Hist. Nat. 2005, 78, 723-737. [CrossRef]

10. Biggs, J.; Williams, P.; Whitfield, M.; Nicolet, P.; Brown, C.; Hollis, J.; Arnold, D.; Pepper, T. The freshwater biota of British agricultural landscapes and their sensitivity to pesticides. Agric. Ecosyst. Environ. 2007, 122, 137-148. [CrossRef]

11. Epele, L.B.; Manzo, L.M.; Grech, M.G.; Macchi, P.; Claverie, A.Ñ.; Lagomarsino, L.; Miserendino, M.L. Disentangling natural and anthropogenic influences on Patagonian pond water quality. Sci. Total Environ. 2018, 613-614, 866-876. [CrossRef] [PubMed]

12. Lemmens, P.; Mergeay, J.; Bie, T.D.; Wichelen, J.V.; Meester, L.D.; Declerck, S.A.J. How to Maximally Support Local and Regional Biodiversity in Applied Conservation? Insights from Pond Management. PLoS ONE 2013, 8, e72538. [CrossRef] [PubMed]

13. Hassall, C.; Hill, M.; Gledhill, D.; Biggs, J. The ecology and management of urban pondscapes. In Urban Landscape Ecology: Science, Policy and Practice; Francis, R.A., Millington, J.D.A., Chadwick, M.A., Eds.; Routledge: Abingdon-on-Thames, UK, 2016; pp. 129-147.

14. Hassall, C. The ecology and biodiversity of urban ponds. WIREs Water 2014, 1, 187-206. [CrossRef]

15. Chester, E.T.; Robson, B.J. Anthropogenic refuges for freshwater biodiversity: Their ecological characteristics and management. Biol. Conserv. 2013, 166, 64-75. [CrossRef]

16. Williams, P.; Whitfield, M.; Biggs, J.; Bray, S.; Fox, G.; Nicolet, P.; Sear, D. Comparative biodiversity of rivers, streams, ditches and ponds in an agricultural landscape in Southern England. Biol. Conserv. 2004, 115, 329-341. [CrossRef]

17. Joniak, T.; Kuczyńska-Kippen, N.; Nagengast, B. The role of aquatic macrophytes in microhabitatual transformation of physical-chemical features of small water bodies. Hydrobiologia 2007, 584, 101-109. [CrossRef]

18. Rosset, V.; Angélibert, S.; Arthaud, F.; Bornette, G.; Robin, J.; Wezel, A.; Vallod, D.; Oertli, B. Is eutrophication really a major impairment for small waterbody biodiversity? J. Appl. Ecol. 2014, 51, 415-425. [CrossRef]

19. Vanacker, M.; Wezel, A.; Arthaud, F.; Guérin, M.; Robin, J. Determination of tipping points for aquatic plants and water quality parameters in fish pond systems: A multi-year approach. Ecol. Indic. 2016, 64, 39-48. [CrossRef]

20. Gioria, M.; Schaffers, A.; Bacaro, G.; Feehan, J. The conservation value of farmland ponds: Predicting water beetle assemblages using vascular plants as a surrogate group. Biol. Conserv. 2010, 143, 1125-1133. [CrossRef] 
21. Søndergaard, M.; Moss, B. Impact of Submerged Macrophytes on Phytoplankton in Shallow Freshwater Lakes. In The Structuring Role of Submerged Macrophytes in Lakes; Jeppesen, E., Søndergaard, M., Søndergaard, M., Christoffersen, K., Eds.; Springer: New York, NY, USA, 1998; Volume 131, pp. 115-132.

22. Gledhill, D.G.; James, P.; Davies, D.H. Pond density as a determinant of aquatic species richness in an urban landscape. Landsc. Ecol. 2008, 23, 1219-1230. [CrossRef]

23. Svitok, M.; Hrivnák, R.; Ot'ahel'ová, H.; Dúbravková, D.; Pal'ove-Balang, P.; Slobodník, V. The importance of local and regional factors on the vegetation of created wetlands in Central Europe. Wetlands 2011, 31, 663-674. [CrossRef]

24. Scheffer, M.; Geest, G.J.V.; Zimmer, K.; Jeppesen, E.; Søndergaard, M.; Butler, M.G.; Hanson, M.A.; Declerck, S.; Meester, L.D. Small habitat size and isolation can promote species richness: Second-order effects on biodiversity in shallow lakes and ponds. Oikos 2006, 112, 227-231. [CrossRef]

25. Akasaka, M.; Takamura, N.; Mitsuhashi, H.; Kadono, Y. Effects of land use on aquatic macrophyte diversity and water quality of ponds. Freshw. Biol. 2010, 55, 909-922. [CrossRef]

26. Svitok, M.; Novikmec, M.; Hamerlík, L.; Kochjarová, J.; Ot’ahel'ová, H.; Pal’ove-Balang, P.; Senko, D.; Matúšová, Z.; Bubíková, K.; Hrivnák, R. Test of the efficiency of environmental surrogates for the conservation prioritization of ponds based on macrophytes. Ecol. Indic. 2018, 95, 606-614. [CrossRef]

27. Pätzig, M.; Kalettka, T.; Glemnitz, M.; Berger, G. What governs macrophyte species richness in kettle hole types? A case study from Northeast Germany. Limnologica 2012, 42, 340-354. [CrossRef]

28. Van Donk, E.; van de Bund, W.J. Impact of submerged macrophytes including charophytes on phyto- and zooplankton communities: Allelopathy versus other mechanisms. Aquat. Bot. 2002, 72, 261-274. [CrossRef]

29. Fontanarrosa, M.S.; Allende, L.; Rennella, A.M.; Boveri, M.B.; Sinistro, R. A novel device with macrophytes and bio balls as a rehabilitation tool for small eutrophic urban ponds: A mesocosm approximation. Limnologica 2019, 74, 61-72. [CrossRef]

30. Beck, M.W.; Tomcko, C.M.; Valley, R.D.; Staples, D.F. Analysis of macrophyte indicator variation as a function of sampling, temporal, and stressor effects. Ecol. Indic. 2014, 46, 323-335. [CrossRef]

31. Pálffy, K.; Présing, M.; Vörös, L. Diversity patterns of trait-based phytoplankton functional groups in two basins of a large, shallow lake (Lake Balaton, Hungary) with different trophic state. Aquat. Ecol. 2013, 47, 195-210. [CrossRef]

32. Barko, J.W.; James, W.F. Effects of Submerged Aquatic Macrophytes on Nutrient Dynamics, Sedimentation, and Resuspension. In The Structuring Role of Submerged Macrophytes in Lakes; Jeppesen, E., Søndergaard, M., Søndergaard, M., Christoffersen, K., Eds.; Springer: New York, NY, USA, 1998; Volume 131, pp. 197-214.

33. Elbanowska, H.; Zerbe, J.; Siepak, J. Phisco-Chemical Water Analyses [Fizyczno-Chemiczne Badania Wód]; Wydaw. Uczelniane UAM: Poznań, Poland, 1999.

34. Sala, J.; Gascón, S.; Boix, D.; Gesti, J.; Quintana, X.D. Proposal of a rapid methodology to assess the conservation status of Mediterranean wetlands and its application in Catalunya (NE Iberian Peninsula). Arch. Sci. 2004, 57, 141-152.

35. Dzwonko, Z. Guidebook to Phytosociological Studies; Wydawnictwo Sorus: Poznań, Poland, 2007.

36. Dufrêne, M.; Legendre, P. Species assemblages and indicator species: The need for a flexible asymmetrical approach. Ecol. Monogr. 1997, 67, 345-366. [CrossRef]

37. The Plant List. Available online: http://www.theplantlist.org (accessed on 17 July 2018).

38. Šmilauer, P.; Lepš, J. Multivariate Analysis of Ecological Data Using CANOCO; Cambridge University Press: Cambridge, UK, 2003.

39. Poikane, S.; Portielje, R.; Denys, L.; Elferts, D.; Kelly, M.; Kolada, A.; Mäemets, H.; Phillips, G.; Søndergaard, M.; Willby, N.; et al. Macrophyte assessment in European lakes: Diverse approaches but convergent views of 'good' ecological status. Ecol. Indic. 2018, 94, 185-197. [CrossRef] [PubMed]

40. Kłosowski, S. The Relationships between Environmental Factors and the Submerged Potametea Associations in Lakes of North-eastern Poland. Hydrobiologia 2006, 560, 15-29. [CrossRef]

41. Kłosowski, S.; Jabłońska, E. Aquatic and swamp plant communities as indicators of habitat properties of astatic water bodies in north-eastern Poland. Limnologica 2009, 39, 115-127. [CrossRef]

42. Szańkowski, M.; Kłosowski, S. Habitat variability of the Littorelletea uniflorae plant communities in Polish Lobelia lakes. Hydrobiologia 2006, 570, 117-126. [CrossRef]

43. Bosiacka, B.; Radziszewicz, M. Vegetation of mid-field water bodies in the city and commune of Kołobrzeg. Bad. Fizjogr. Pol. Zach. Ser. B 2003, 52, 81-108. 
44. Klosowski, S.; Tomaszewicz, H.; Tomaszewicz, G. Standortsbedingungen des Calletum palustris, Menyanthetum trifoliatae und Potentilletum palustris in Nordost-Polen. Tuexenia 1995, 15, 205-219.

45. Zhang, Q.; Liu, Y.P.; Luo, F.L.; Dong, B.C.; Yu, F.H. Does species richness affect the growth and water quality of submerged macrophyte assemblages? Aquat. Bot. 2019, 153, 51-57. [CrossRef]

46. Coppens, J.; Hejzlar, J.; Šorf, M.; Jeppesen, E.; Erdoğan, S.; Scharfenberger, U.; Mahdy, A.; Nõges, P.; Tuvikene, A.; Baho, D.L.; et al. The influence of nutrient loading, climate and water depth on nitrogen and phosphorus loss in shallow lakes: A pan-European mesocosm experiment. Hydrobiologia 2016, 778, 13-32. [CrossRef]

47. Tessier, A.J.; Woodruff, P. Cryptic Trophic Cascade along a Gradient of Lake Size. Ecology 2002, 83, $1263-1270$. [CrossRef]

48. Geest, G.J.V.; Coops, H.; Roijackers, R.M.M.; Buijse, A.D.; Scheffer, M. Succession of aquatic vegetation driven by reduced water-level fluctuations in floodplain lakes. J. Appl. Ecol. 2005, 42, 251-260. [CrossRef]

49. O'Farrell, I.; Izaguirre, I.; Chaparro, G.; Unrein, F.; Sinistro, R.; Pizarro, H.; Rodríguez, P.; de Tezanos Pinto, P.; Lombardo, R.; Tell, G. Water level as the main driver of the alternation between a free-floating plant and a phytoplankton dominated state: A long-term study in a floodplain lake. Aquat. Sci. 2011, 73, $275-287$. [CrossRef]

50. Wang, S.; Gao, Y.; Li, Q.; Gao, J.; Zhai, S.; Zhou, Y.; Cheng, Y. Long-term and inter-monthly dynamics of aquatic vegetation and its relation with environmental factors in Taihu Lake, China. Sci. Total Environ. 2019, 651, 367-380. [CrossRef] [PubMed]

51. Bouraoui, F.; Grizzetti, B.; Granlund, K.; Rekolainen, S.; Bidoglio, G. Impact of Climate Change on the Water Cycle and Nutrient Losses in a Finnish Catchment. Clim. Chang. 2004, 66, 109-126. [CrossRef]

52. Carr, G.M.; Duthie, H.C.; Taylor, W.D. Models of aquatic plant productivity: A review of the factors that influence growth. Aquat. Bot. 1997, 59, 195-215. [CrossRef]

53. Grīnberga, L.; Springe, G. Potential Impact of Climate Change on Aquatic Vegetation of River Salaca, Latvia. Proc. Latv. Acad. Sci. B Nat. Exact. Appl. Sci. 2008, 62, 34-39. [CrossRef]

54. Ecke, F. Drainage ditching at the catchment scale affects water quality and macrophyte occurrence in Swedish lakes. Freshw. Biol. 2008, 54, 119-126. [CrossRef]

55. Pedersen, O.; Andersen, T.; Ikejima, K.; Hossain, M.Z.; Andersen, F.Ø. A multidisciplinary approach to understanding the recent and historical occurrence of the freshwater plant, Littorella uniflora. Freshw. Biol. 2006, 51, 865-877. [CrossRef]

56. Søndergaard, M.; Jeppesen, E.; Jensen, J.P. Pond or lake: Does it make any difference? Arch. Hydrobiol. 2005, 162, 143-165. [CrossRef]

57. Huang, Z.; Han, L.; Zeng, L.; Xiao, W.; Tian, Y. Effects of land use patterns on stream water quality: A case study of a small-scale watershed in the Three Gorges Reservoir Area, China. Environ. Sci. Pollut. Res. 2016, 23, 3943-3955. [CrossRef]

58. De Mello, K.; Valente, R.A.; Randhir, T.O.; Vettorazzi, C.A. Impacts of tropical forest cover on water quality in agricultural watersheds in southeastern Brazil. Ecol. Indic. 2018, 93, 1293-1301. [CrossRef]

59. Wang, L.W.; Showalter, A.M.; Ungar, I.A. Effect of salinity on growth, ion content, and cell wall chemistry in Atriplex prostrata (Chenopodiaceae). Am. J. Bot. 1997, 84, 1247-1255. [CrossRef] [PubMed]

60. Yuan, G.; Fu, H.; Zhong, J.; Cao, T.; Ni, L.; Zhu, T.; Li, W.; Song, X. Nitrogen/carbon metabolism in response to NH4+ pulse for two submersed macrophytes. Aquat. Bot. 2015, 121, 76-82. [CrossRef]

61. Levi, P.S.; Riis, T.; Alnøe, A.B.; Peipoch, M.; Maetzke, K.; Bruus, C.; Baattrup-Pedersen, A. Macrophyte Complexity Controls Nutrient Uptake in Lowland Streams. Ecosystems 2015, 18, 914-931. [CrossRef]

62. Baker, T.J.; Miller, S.N. Using the Soil and Water Assessment Tool (SWAT) to assess land use impact on water resources in an East African watershed. J. Hydrol. 2013, 486, 100-111. [CrossRef]

63. Zhang, Y.; Liu, X.; Qin, B.; Shi, K.; Deng, J.; Zhou, Y. Aquatic vegetation in response to increased eutrophication and degraded light climate in Eastern Lake Taihu: Implications for lake ecological restoration. Sci. Rep. 2016, 6, 23867. [CrossRef] [PubMed]

64. Conley, D.J.; Paerl, H.W.; Howarth, R.W.; Boesch, D.F.; Seitzinger, S.P.; Havens, K.E.; Lancelot, C.; Likens, G.E. Controlling Eutrophication: Nitrogen and Phosphorus. Science 2009, 323, 1014-1015. [CrossRef] [PubMed]

65. Epele, L.B.; Miserendino, M.L. Temporal dynamics of invertebrate and aquatic plant communities at three intermittent ponds in livestock grazed Patagonian wetlands. J. Nat. Hist. 2016, 50, 711-730. [CrossRef] 
66. Chust, G.; Pretus, J.L.; Ducrot, D.; Ventura, D. Scale dependency of insect assemblages in response to landscape pattern. Landsc. Ecol 2004, 19, 41-57. [CrossRef]

67. Schmidt, M.H.; Thies, C.; Nentwig, W.; Tscharntke, T. Contrasting responses of arable spiders to the landscape matrix at different spatial scales. J. Biogeogr. 2008, 35, 157-166. [CrossRef]

(C) 2019 by the authors. Licensee MDPI, Basel, Switzerland. This article is an open access article distributed under the terms and conditions of the Creative Commons Attribution (CC BY) license (http://creativecommons.org/licenses/by/4.0/). 